
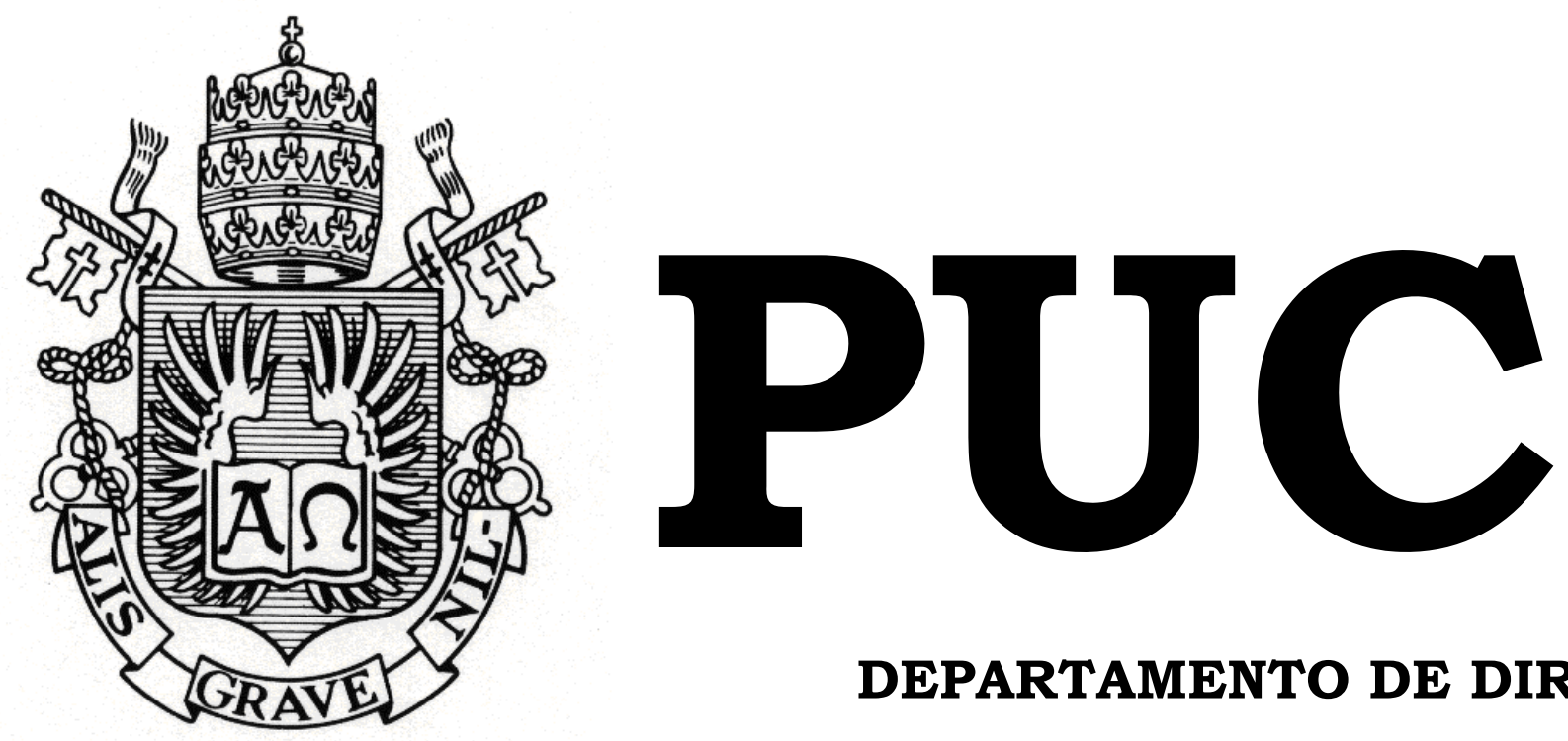

DEPARTAMENTO DE DIREITO

\title{
RESPONSABILIDADE DOS ADMINISTRADORES
}

\author{
por
}

FRANCISCO ZANINOTTO MONT' ALVERNE

ORIENTADOR(A): FELIPE ACIOLY

2010.2

PONTIFÍCIA UNIVERSIDADE CATÓLICA DO RIO DE JANEIRO

RUA MARQUÊS DE SÃO VICENTE, 225 - CEP 22453-900

RIO DE JANEIRO - BRASIL 


\title{
RESPONSABILIDADE DOS ADMINISTRADORES
}

\author{
por \\ FRANCISCO ZANINOTTO MONT' ALVERNE
}

Monografia apresentada ao

Departamento de Direito da Pontificia Universidade Católica do Rio de Janeiro (PUC-Rio) para a obtenção do Título de Bacharel em Direito.

Orientador(a): Felipe Acioly 


\section{RESUMO}

O objeto deste trabalho de monografia é o estudo sobre a responsabilidade dos administradores nos tipos societários empresariais mais utilizados no Brasil. Referido trabalho inicia-se com o estudo das sociedades empresárias, com foco na sua história e nos conceitos e pressupostos inerentes à sua constituição.

Em seguida, serão apresentados os temas atinentes (a) à limitação da responsabilidade patrimonial de acordo com o tipo societário adotado e (b) à desconsideração da personalidade jurídica.

Posteriormente, o administrador será o foco do trabalho para que seja possível compreender os elementos que caracterizaram a administração em uma sociedade empresária.

Finalmente, após terem sido tratados os principais conceitos e princípios referentes às sociedades empresárias, à limitação da responsabilidade nas sociedades empresárias e ao instituto ta administração social, será estudada a responsabilidade dos administradores nas sociedades por ações e nas sociedades de responsabilidade limitada, ressaltando, ainda, as ferramentas jurídicas para a preservação do patrimônio dos administradores.

Palavras-chave: direito comercial; sociedade empresária; responsabilidade patrimonial limitada; desconsideração da personalidade jurídica; responsabilidade pessoal e solidária; administradores; hipóteses de responsabilização; acordo de indenidade; e seguro D\&O. 


\section{SUMÁRIO}

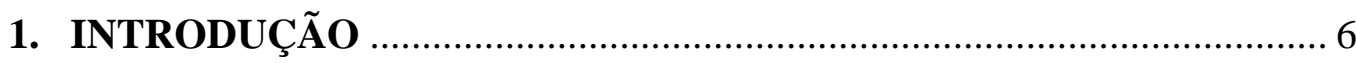

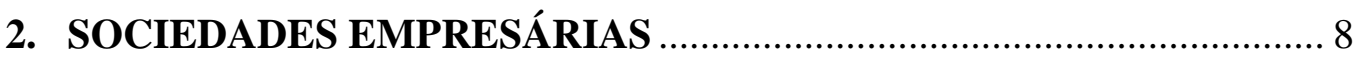

2.1. EVOLUÇÃO HISTÓRICA............................................................... 8

2.1.1. EVOLUÇÃO HISTÓRICA DO DIREITO

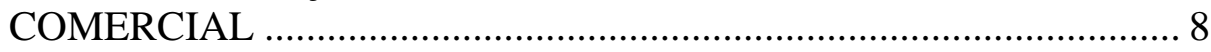

2.1.2. EVOLUÇÃO HISTÓRICA DO DIREITO

COMERCIAL BRASILEIRO_............................................................ 9

2.2. CONCEITO E DIFERENÇAS ENTRE AS SOCIEDADES

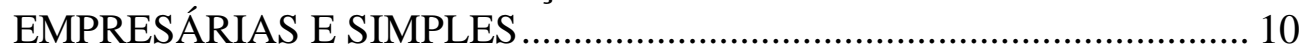

2.3. PRINCÍPIOS QUE REGEM AS SOCIEDADES EMPRESÁRIAS ... 12

2.4. CONSTITUIÇÃO DAS SOCIEDADES EMPRESÁRIAS .................. 13

2.5. REGULARIDADE DA SOCIEDADE EMPRESÁRIA ......................... 14

2.6. CLASSIFICAÇÃO DAS SOCIEDADES EMPRESÁRIAS ................. 16

2.6.1. PELA NATUREZA DO ATO CONSTITUTIVO ................... 17

2.6.2. PELA RESPONSABILIDADE SOCIAL ............................... 17

2.6.3. PELA COMPOSIÇÃO ECONÔMICA …………………….... 18

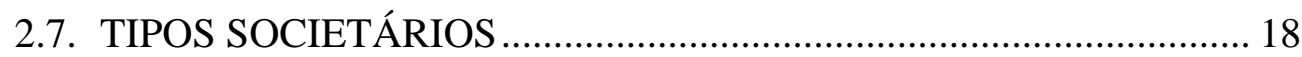

3. RESPONSABILIDADE PATRIMONIAL NAS SOCIEDADES

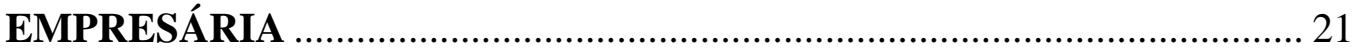

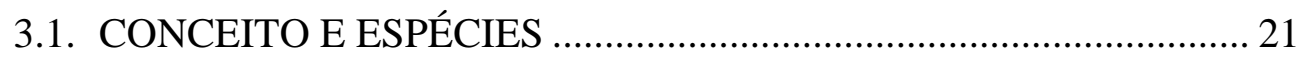

3.2. DESCONSIDERAÇÃO DA PERSONALIDADE JURÍDICA ............ 23

3.2.1. TEORIA MAIOR DA DESCONSIDERAÇÃO

DA PERSONALIDADE JURÍDICA ……………………………..... 24

3.2.2. TEORIA MENOR DA DESCONSIDERAÇÃO DA PERSONALIDADE JURÍDICA..................................................... 26

3.2.3. TEORIA INVERSA DA DESCONSIDERAÇÃO DA PERSONALIDADE JURÍDICA....................................................... 29

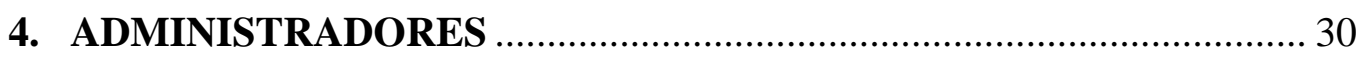

4.1. ADMINISTRADORES DAS SOCIEDADES ANÔNIMAS ................ 30

4.1.1. REQUISITOS …………………………………………... 30 


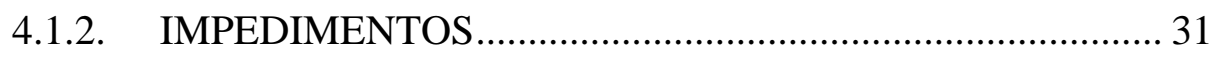

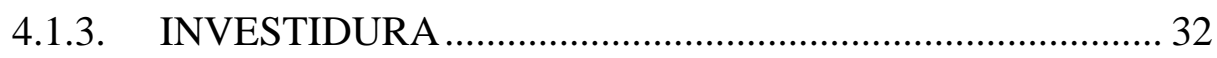

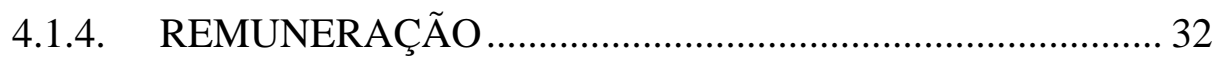

4.2. ADMINISTRADORES DAS SOCIEDADES LIMITADAS .............. 33

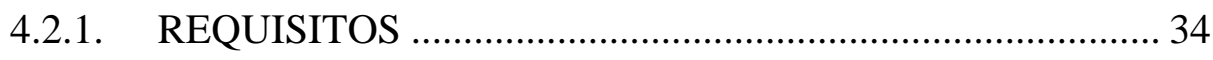

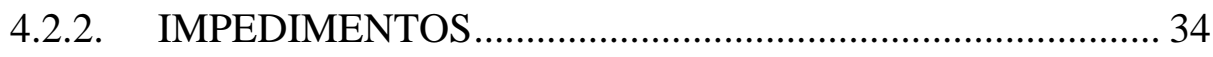

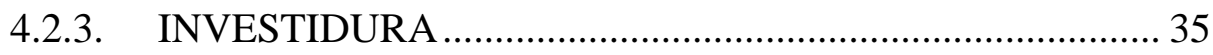

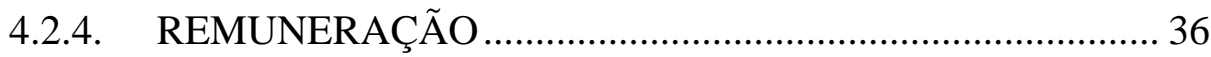

\section{RESPONSABILIDADE DOS ADMINISTRADORES NAS}

5.1. RESPONSABILIDADE DOS ADMINISTRADORES NAS SOCIEDADES LIMITADAS 38

5.1.1. RESPONSABILIDADE PESSOAL E SOLIDÁRIA ............ 38

5.1.2. RESPONSABILIDADE ANTES DA AVERBAÇÃO DO ATO DE NOMEAÇÃO............................................................. 39

5.1.3. DEVERES DE CUIDADO E DILIGÊNCIA ......................... 39

5.1.4. DEVER DE ATUAR DE ACORDO A COM MAIORIA DOS VOTOS DOS SÓCIOS ............................................. 40

5.1.5. EXCESSO NO EXERCÍCIO DO CARGO DE ADMINISTRADOR 40

5.1.6. RESPONSABILIDADE POR ATOS EM BENEFÍCIO PRÓPRIO OU DE TERCEIROS

5.1.7. RESPONSABILIDADE POR DISTRIBUIÇÃO IRREGULAR DE DIVIDENDOS ...

5.2. RESPONSABILIDADE DOS ADMINISTRADORES NAS

SOCIEDADES ANÔNIMAS 43

5.2.1. RESPONSABILIDADE PESSOAL E SOLIDÁRIA ............ 43

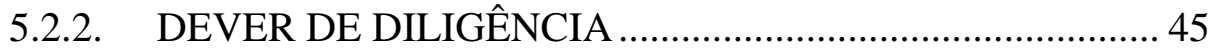

5.2.3. RESPONSABILIDADE POR DESVIO DE FINALIDADE E ATRIBUIÇÕES …............................................... 46

5.2.4. DEVER DE LEALDADE .................................................. 47

5.2.5. RESPONSABILIDADE POR CONFLITO DE

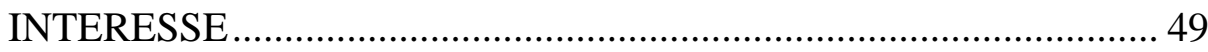

5.2.6. DEVER DE INFORMAÇÃO AO MERCADO ..................... 50

5.2.7. RESPONSABILIDADE POR DISTRIBUIÇÃO IRREGULAR DE DIVIDENDOS 
5.3. OUTRAS HIPÓTESES DE RESPONSABILIZAÇÃO DOS ADMINISTRADORES NAS SOCIEDADES EMPRESÁRIAS

5.3.1. RESPONSABILIDADE NO ÂMBITO DO

CÓDIGO PENAL ……………………………………………...... 54

5.3.2. RESPONSABILIDADE POR CONDUTAS

LESIVAS AO MEIO AMBIENTE ....................................................... 55

5.3.3. RESPONSABILIDADE NO ÂMBITO

TRABALHISTA E PREVIDENCIÁRIO 56

5.3.4. RESPONSABILIDADE NO ÂMBITO FALIMENTAR ....... 57

5.3.5. RESPONSABILIDADE NO ÂMBITO FISCAL .................... 59

6. PRÁTICAS PARA PRESERVAÇÃO DO PATRIMÔNIO DOS

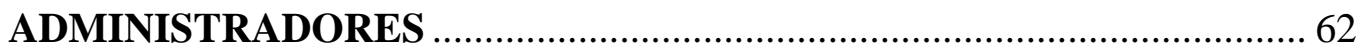

6.1. ACORDO DE INDENIDADE (HOLD HARMLESS LETTER)........... 62

6.2. SEGURO PARA RESPONSABILIDADE CIVIL DE

ADMINISTRADORES (DIRECTORS AND

OFFICERS INSURANCE).....

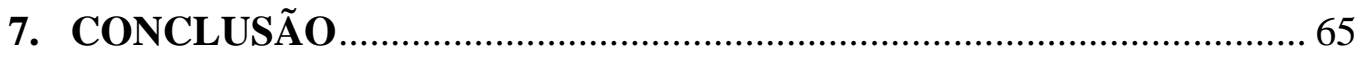

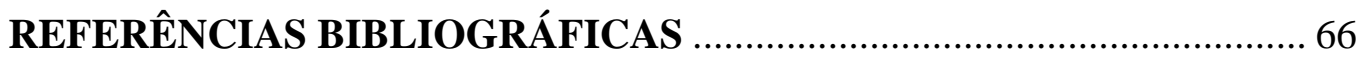




\section{INTRODUÇÃO}

Desde a antiguidade já era possível observar algumas civilizações que praticavam atividades que foram o princípio do que conhecemos como comércio, o qual é considerado a base para o surgimento das sociedades empresárias.

Tais atividades ganharam força na Idade Média, apresentaram forte expressão a partir da revolução francesa e continuam a evoluir até os dias de hoje.

Para o exercício destas atividades surgiram às sociedades e, posteriormente, as sociedades empresárias. Uma sociedade empresária é aquela formada, em regra, pela união de esforços de duas ou mais pessoas devido a interesses relacionados à obtenção de resultados econômicos por meio do exercício de atividades empresárias que serão exercidas de forma a reunir e organizar os elementos de produção (i.e. força de trabalho, matériaprima, capital e tecnologia).

Vale ressaltar que, tendo em vista a evolução histórica das atividades empresárias e da economia, alguns tipos societários utilizados pelas sociedades empresárias acabaram por cair em desuso (e.g. sociedades em nome coletivo e sociedades em comandita simples) e, portanto, não serão objeto de maiores estudos no presente trabalho.

Atualmente, dois tipos societários são adotados majoritariamente para o exercício de atividades de natureza empresarial, quais sejam: (i) a Sociedade de Responsabilidade Limitada, regida precipuamente pela Lei ${ }^{\circ}$ 10.406/2002 (“CC”); e (ii) a Sociedade por Ações, regida pela Lei ${ }^{\circ}$ 6.404/76 (“LSA”).

A principal razão para as sociedades empresárias terem se tornado os tipos societários mais adotados para o exercício de atividades empresariais é a existência da limitação da responsabilidade patrimonial de seus sócios/acionistas, característica esta que permite limitar os riscos do negócio ao patrimônio da pessoa jurídica. 
As sociedades empresárias, mesmo dotadas de personalidade jurídica própria e autonomia patrimonial, são estruturas administradas e conduzidas por pessoas através dos órgãos deliberativos e administrativos dotados de poderes para tomar decisões e realizar atos em nome da sociedade, desde que de acordo com a função social da sociedade, com as disposições estatutárias, com a legislação aplicável e com os bons costumes.

Nesse sentido, as sociedades empresárias impõem que seus administradores, no exercício de suas atividades, atuem com diligência, lealdade e informação, cabendo ao administrador materializar o interesse da sociedade de forma honesta, competente e eficiente.

Conseqüentemente, perante a inobservância do contrato/estatuto social ou das disposições legais aplicáveis, ou ainda em casos em que os administradores tenham causado prejuízos agindo com dolo ou culpa, poderão estes vir a serem responsabilizados.

Referidas hipóteses de responsabilização poderão ter natureza administrativa, cível e/ou criminal, cabendo, inclusive, a responsabilização pessoal dos administradores pelos danos causados à sociedade e a terceiros.

Atualmente, tendo em vista as inúmeras hipóteses de responsabilização dos administradores das sociedades empresárias, alguns recursos vêm sendo discutidos para proteger o patrimônio das pessoas físicas que venham a assumir e exercer cargos de administração em sociedades empresárias, como, por exemplo, algumas formas de seguro (e.g. $D \& O)$ ou instrumentos de garantia (hold harmless letters).

Assim, tendo em vista o exposto acima, o presente trabalho de monografia discorrerá sobre o instituto da responsabilidade dos administradores das sociedades empresárias.

Para tanto, será preciso discorrer, também, sobre outros temas acessórios que auxiliarão na compreensão do referido instituto, como, por exemplo, (a) a evolução histórica das sociedades empresárias; (b) a limitação da responsabilidade patrimonial nas sociedades empresárias; e (c) os pressupostos caracterizadores da administração, dentre outros. 


\section{SOCIEDADES EMPRESÁRIAS}

\subsection{EVOLUÇÃO HISTÓRICA}

\subsubsection{EVOLUÇÃO HISTÓRICA DO DIREITO COMERCIAL}

As regras acerca do Direito Comercial sempre estiveram presentes nas normativizações, inclusive nas mais antigas, como o Código de Hammurabi, por exemplo. No entanto, não existiu um conjunto consolidado de normas sobre o comércio até a proliferação dos institutos da propriedade privada/particular e das atividades econômicas, que se expressaram por meio das corporações medievais durante o feudalismo.

Nesse sentido, é possível considerar que a evolução do Direito Comercial, basicamente, foi dividida em quatro períodos. Na metade do século XII, por meio das corporações de ofícios, iniciou-se o primeiro período de evolução do Direito Comercial, onde as referidas corporações formaram jurisdições próprias reguladas pelos usos e costumes de seus participantes.

Vale ressaltar que, ainda no primeiro período histórico, foram implementados alguns dos mais importantes institutos do Direito Comercial, como, por exemplo, o seguro, a letra de câmbio e as instituições financeiras.

Como marco da segunda etapa evolutiva do Direito Comercial, tivemos a criação da sociedade anônima, detentora de uma estrutura adequada aos vultosos empreendimentos mercantis realizados em razão da expansão colonial.

Posteriormente, com a codificação napoleônica, inicia-se o terceiro período de evolução do Direito Comercial, onde efetivamente houve a objetivação deste ramo do direito, que naquele momento passava a ser uma disciplina jurídica aplicável a atos e não a sujeitos em si, ou seja, qualquer pessoa poderia exercer atividade mercantil, desfrutando de alguns 
privilégios frutos de uma disciplina jurídica específica, e não somente aqueles que participassem das corporações de ofício. Por isso, a teoria que marca este período foi chamada de Teoria dos Atos do Comércio, que, basicamente, consiste em abranger, no âmbito do Direito Comercial, aqueles atos considerados como atos de comércio praticados pela burguesia francesa e, conseqüentemente, reconhecer como comerciantes aqueles que praticam tais atos, atribuindo a estes os direitos e as obrigações pertinentes.

Por fim, em 1942, na quarta e última fase evolutiva do Direito Comercial, o Código Civil Italiano passou a regular, conjuntamente, as matérias cíveis e comerciais, ou seja, o referido diploma normativo uniformizou a legislação do Direito Privado, apresentando uma teoria substitutiva à Teoria dos Atos de Comércio. Referida teoria passou a ser conhecida como a Teoria da Empresa, onde a base do Direito Comercial deixou de ser os atos de comércio da Teoria dos Atos de Comércio e passou a ser o conceito de empresa. Nesse sentido, empresa deve ser entendida como sendo a atividade que visa à obtenção de lucros através da disponibilização de bens e/ou serviços, através da organização dos fatores de produção (i.e. força de trabalho, matéria-prima, capital e tecnologia). Outrossim, a empresa não seria mais confundida com o sujeito, sendo este o empresário, ou com a coisa, sendo esta o estabelecimento comercial, tornado-se, portanto, atividade econômica, profissional e organizada.

\subsubsection{EVOLUÇÃO HISTÓRICA DO DIREITO COMERCIAL BRASILEIRO}

O Direito Comercial brasileiro teve inicio com a abertura dos portos decretada com a Carta Régia datada de 28.1.1808. Ainda em 1808, outros relevantes atos que disciplinavam o comércio foram produzidos, tais como: (a) o alvará que autorizava o livre estabelecimento de fábricas e manufaturas, datado de 12.4.1808; (b) o alvará criador do Tribunal da Real 
Junta do Comércio, Agricultura, Fabricas e Navegação, datado de 23.8.1808; e (c) o alvará criador do Banco do Brasil, datado de 12.10.1808.

Posteriormente, quando o Brasil já havia se tornado um importante local de investimento para as nações européias e havia uma carência por uma legislação comercial própria hábil a atender ao desenvolvimento econômico vivido naquele momento, veio a ser aprovado, em 1850, o Código Comercial Brasileiro.

Mesmo não havendo menções aos atos de comércio da Teoria dos Atos de Comércio, o referido Código Comercial Brasileiro tinha como base esta teoria.

Apenas por volta de 1960 o direito brasileiro começou a se aproximar da Teoria da Empresa. Referida aproximação foi alvo de diversas tentativas que foram se aperfeiçoando até que, finalmente, o ordenamento jurídico brasileiro, por meio da entrada em vigor do CC, amparou a Teoria da Empresa como base do Direito Comercial brasileiro.

Assim, empresário e sociedade empresária passaram a ser o profissional e a sociedade exercente de atividade econômica organizada para a produção ou circulação de bens ou de serviços ${ }^{1}$, permanecendo sujeito às disposições de lei pertinentes à matéria mercantil ${ }^{2}$. Entretanto, não é considerado empresário quem exerce atividade intelectual, de natureza científica, literária ou artística, mesmo que conte com o concurso de auxiliares ou colaboradores, salvo se constituir o exercício da profissão elemento de empresa ${ }^{3}$.

\subsection{CONCEITO E DIFERENÇAS ENTRE AS SOCIEDADES EMPRESÁRIAS E SIMPLES}

No direito brasileiro, duas são as espécies de sociedades: (a) a sociedade simples; e (b) a sociedade empresária.

\footnotetext{
1 Artigo 966 do CC e Artigo 982 do CC.

2 Artigo 2037 do CC.

3 Parágrafo único do artigo 966 do CC.
} 
A sociedade empresária é aquela que exerce atividade econômica organizada para a produção ou circulação de bens ou de serviços, com base na Teoria do Elemento de Empresa, visando o lucro a ser partilhado entre as pessoas que a compõem.

Normalmente, uma sociedade empresária diferencia-se de uma sociedade simples através do objeto social. Desta forma, uma sociedade será considerada empresária quando exercer atividade econômica organizada para a produção ou circulação de bens ou de serviços.

Quanto às sociedades empresárias, explica José Edwaldo Tavares Borba ${ }^{4}$ :

"A atividade empresarial é a marca de sua classificação como sociedade empresária, ressalvada a sociedade por ações, que é sempre empresária (art. 982, $\S$ único). O fim lucrativo é da essência da sociedade, a qual se destina a produzir lucro, para distribuição aos que participam de seu capital.”.

Outrossim, caso o objeto social não seja de sociedade empresária, mas a sociedade exerça de fato atividade de natureza empresária, esta será considerada como uma sociedade empresária.

Por outro lado, temos que as sociedades simples, são aquelas que exercem atividade intelectual, de natureza científica, literária ou artística, ainda que com o concurso de auxiliares ou colaboradores, salvo se o exercício da profissão constituir elemento de empresa ${ }^{5}$, bem como as demais sociedades que não sejam consideradas empresárias e aquelas que, por força de lei, são definidas como simples (e.g. cooperativas ${ }^{6}$ ).

No entanto, caso uma sociedade simples apresente diversos fatores de produção organizados no exercício de sua atividade, referida sociedade torna-se uma sociedade empresária, uma vez que a uma sociedade não é naturalmente empresária ou não-empresária, tudo depende da maneira em que se encontra organiza a atividade representativa de seu objeto social.

\footnotetext{
4 BORBA, José Edwaldo Tavares. Direito Societário. 8a ed. Rio de Janeiro: Renovar, 2003. p 18.

5 Parágrafo único do artigo 966 do CC.

6 Parágrafo único do artigo 982 do CC.
} 
Outra diferença importante é que as sociedades empresárias estão sujeitas ao instituto da falência e da recuperação judicial, ambos regulados pela Lei 11.101/2005 que instituiu a Lei de Falências (“LRF”)", enquanto as sociedades simples estão sujeitas ao instituto da insolvência civil regulado pelo CC.

Adicionalmente, os atos constitutivos das sociedades empresárias deverão ser arquivados nas pertinentes Juntas Comerciais ${ }^{8}$ e os das sociedades simples no Registro Civil de Pessoa Jurídica9 .

Ressalta-se, ainda, que existem certas sociedades que, devido ao seu objeto social, apresentam uma natureza mista de sociedade empresária e simples. Nesses casos, temos uma sociedade de objeto misto que terá sua natureza fixada em razão da atividade preponderante exercida por ela.

\subsection{PRINCÍPIOS QUE REGEM AS SOCIEDADES EMPRESÁRIAS}

Quanto à sociedade empresária, vale ressaltar que existem dois princípios basilares que regulam sua normativização, quais sejam: (a) a sociedade empresária é constituída por um instrumento de organização plurilateral; e (b) a sociedade empresária tem personalidade jurídica de pessoa jurídica de direito privado.

Adicionalmente, existem, ainda, outros princípios societários de caráter implícito de importante aplicação às sociedades empresárias, tais como: (a) defesa da minoria societária; (b) tutela da pequena e média empresa; (c) controle jurisdicional; (d) conservação da empresa; (e) liberdade de contratar e autonomia da vontade; (f) responsabilidade societária; e (g) legalidade.

\footnotetext{
Artigo $1^{\circ}$ da LRF.

8 Artigo 967 do CC.

9 Artigo 988 do CC.
} 


\subsection{CONSTITUIÇÃO DAS SOCIEDADES EMPRESÁRIAS}

As sociedades são constituídas a partir do interesse comum de associar-se (i.e. pelo affectio societatis), por meio de um instrumento de constituição pluriparteal, lastreado no princípio de que o pacto é o consenso ou convenção de dois, ou seja, pactum est duorum consensus atque convenio.

Nesse sentido, tendo em vista a natureza jurídica de negócio jurídico dos instrumentos de constituição das sociedades, o CC dispõe acerca de alguns requisitos de validade desde instrumento de constituição, quais sejam: (a) agente capaz, (b) objeto lícito e (c) forma prescrita ou não defesa em lei ${ }^{10}$.

Agente capaz é aquele que apresenta pleno exercício das atividades civis, ressalvado o menor que pode ser admitido como sócio em uma sociedade desde que seja assistido ou representado, esteja com sua parte representativa do capital social totalmente integralizada e não tenha poderes de administração ou gerência da sociedade que o admitiu.

Quanto ao objeto, temos que a atividade explorada pela sociedade deve ser uma atividade não proibida em lei, devendo, ainda, ser uma atividade determinável.

Finalmente, em relação à forma, temos que esta deverá sempre ser escrita, poderá ser materializada por instrumento particular ou público, conforme disposição legal aplicável.

Além dos requisitos de validade aplicáveis a qualquer negócio jurídico, é necessário o registro da sociedade empresária perante a pertinente Junta Comercial para que esta adquira personalidade jurídica, a qual será concedida após aprovação do respectivo pedido de registro que

\footnotetext{
${ }^{10}$ Artigo 104 do CC.
} 
analisará os requisitos formais dispostos no artigo 56 da Lei $n^{\circ} 8.884 / 94^{11} \mathrm{e}$ no artigo 53, inciso III, do Decreto $n^{\circ} 1.800 / 96^{12}$.

Portanto, concluí-se que, nos instrumentos de constituição das sociedades, há um conteúdo misto entre a liberdade de contratar e a cogência normativa, uma vez que o instrumento de constituição é composto por duas espécies de cláusulas, as (a) cláusulas cogentes, conforme parágrafo acima, assim chamadas por decorrerem de imposições legais, e (b) cláusulas dispositivas de livre pactuação entre os sócios, limitadas, sempre, a não violação da lei, dos bons costumes e dos princípios societários aplicáveis (e.g. forma de eleição dos administradores, prazo de duração da sociedade, processo dissolutório da sociedade).

\subsection{REGULARIDADE DA SOCIEDADE EMPRESÁRIA}

A sociedade empresária, para ser considerada uma sociedade regular e, com isso, gozar de toda a proteção legal aplicável a ela, deverá, cumulativamente: (a) estar registrada na competente Junta Comercial, conforme artigo 967 do CC; (b) escriturar regularmente os livros

11 Artigo 56 da Lei 8.884/94 “As Juntas Comerciais ou órgãos correspondentes nos Estados não poderão arquivar quaisquer atos relativos à constituição, transformação, fusão, incorporação ou agrupamento de empresas, bem como quaisquer alterações, nos respectivos atos constitutivos, sem que dos mesmos conste: I - a declaração precisa e detalhada do seu objeto; II - o capital de cada sócio e a forma e prazo de sua realização; III - o nome por extenso e qualificação de cada um dos sócios acionistas; IV - o local da sede e respectivo endereço, inclusive das filiais declaradas; V - os nomes dos diretores por extenso e respectiva qualificação; VI - o prazo de duração da sociedade; VII - o número, espécie e valor das ações.”.

12 Artigo 53, inciso III, do Decreto n 1.800/96 "Não podem ser arquivados: (...)III - os atos constitutivos e os de transformação de sociedades mercantis, se deles não constarem os seguintes requisitos, além de outros exigidos em lei: a) o tipo de sociedade mercantil adotado; b) a declaração precisa e detalhada do objeto social; c) o capital da sociedade mercantil, a forma e o prazo de sua integralização, o quinhão de cada sócio, bem como a responsabilidade dos sócios; d) o nome por extenso e qualificação dos sócios, procuradores, representantes e administradores, compreendendo para a pessoa física, a nacionalidade, estado civil, profissão, domicílio e residência, documento de identidade, seu número e órgão expedidor e número de inscrição no Cadastro de Pessoas Físicas - CPF, dispensada a indicação desse último no caso de brasileiro ou estrangeiro domiciliado no exterior, e para a pessoa jurídica o nome empresarial, endereço completo e, se sediada no País, o Número de Identificação do Registro de Empresas NIRE ou do Cartório competente e o número de inscrição no Cadastro Geral de Contribuintes CGC; e) o nome empresarial, o município da sede, com endereço completo, e foro, bem como os endereços completos das filiais declaradas; f) o prazo de duração da sociedade mercantil e a data de encerramento de seu exercício social, quando não coincidente com o ano civil;”. 
obrigatórios ao seu tipo societário e atividade exercida, quando aplicável; e (c) levantar o balanço patrimonial e de resultado econômico anuais ${ }^{13}$.

Quanto ao item (a) acima, cabe ressaltar que a sociedade que está em fase de constituição não será considerada irregular e sim "em comum"14, dentro do prazo de trinta dias de sua constituição até o registro desta perante o órgão de registro competente ${ }^{15}$. Entende-se como fase de constituição o lapso temporal que se inicia com a assinatura do instrumento de constituição e prossegue durante o tempo necessário para a sociedade estar apta a ser registrada.

Quanto ao empresário rural, vale apontar que a inscrição deste é facultativa ${ }^{16}$. Sem ela a atividade é regular, porém, não é considerada empresária. A atividade será considerada empresária somente quando do registro como sociedade empresária. O registro nesse caso, apresenta, portanto, caráter constitutivo e não declaratório.

No que se refere ao item (b) acima, é importante apontar que os livros societários obrigatórios variarão conforme o tipo societário escolhido para a constituição da sociedade e, às vezes, conforme as atividades exercidas pela sociedade.

Por outro lado, a obrigação de levantar os balanços mencionados no item (c) acima, anualmente, por meio dos quais serão demonstrados o ativo e o passivo da sociedade, é imposta a todos os empresários e sociedades empresárias.

Caso a sociedade empresária não observe tais requisitos e, portanto, seja considerada como uma sociedade irregular, a sociedade estará exposta as seguintes conseqüências: (a) impossibilidade de pedir falência de seus devedores ${ }^{17}$, mas podendo ter a sua falência decretada ou requerer a

\footnotetext{
${ }^{13}$ Artigo 1.179 do CC.

${ }^{14}$ Artigo 986 do CC.

${ }^{15}$ Artigo 998 do CC.

${ }^{16}$ Artigo 971 do CC e Artigo 984 do CC.

${ }^{17}$ Parágrafo primeiro do artigo 97 da LRF.
} 
autofalência; (b) impossibilidade de requerer recuperação judicial ${ }^{18}$; (c) impossibilidade de autenticação de seus livros societários em razão da ausência de inscrição perante órgão competente ${ }^{19}$ - aqui, é importante ressaltar que, se for decretada a falência do empresário irregular, essa falência será fraudulenta ${ }^{20}$, uma vez que os referidos livros não contarão com a eficácia probatória atribuída pelo artigo 379 da Lei 5.869/73 (“CPC”) 21; (d) responsabilidade pelas obrigações sociais, em caráter solidário e ilimitado, por parte dos sócios ${ }^{22}$, ressalvado o período de trinta dias onde a sociedade está legalmente regular por se tratar de fase de constituição; (e) impossibilidade de participar de licitações na modalidade de concorrência pública e tomada de $\operatorname{preços}^{23}$; (f) impossibilidade de inscrição no Cadastro Nacional de Pessoas Jurídicas - CNPJ, no Cadastro de Contribuintes Mobiliários - CCM, perante o Instituto Nacional de Seguridade Social - INSS; e (g) impossibilidade de contratar com o poder público, tendo em vista a irregularidade perante a seguridade social ${ }^{24}$.

\subsection{CLASSIFICAÇÃO DAS SOCIEDADES EMPRESÁRIAS}

A classificação das sociedades empresárias vem sendo objeto de constante debate doutrinário. Tendo em vista que não se trata do objeto principal deste trabalho, serão apresentadas três classificações como as mais relevantes:

\footnotetext{
18 Artigo 51, inciso V da LRF.

19 Artigo 1.181 do CC.

20 Artigo 178 da LRF.

21 Artigo 379 do CPC “Os livros comerciais, que preencham os requisitos exigidos por lei, provam também a favor do seu autor no litígio entre comerciantes.”.

22 Artigo 990 do CC.

23 Artigo 28, incisos II e III da Lei 8.666/1993.

24 Parágrafo 3 do artigo 195 da Constituição da República Federativa do Brasil de 1988 (“CF”).
} 


\subsubsection{PELA NATUREZA DO ATO CONSTITUTIVO}

As sociedades empresárias podem ser constituídas por meio (a) de um contrato social, sendo denominadas como sociedades contratuais, ou (b) de um estatuto social, sendo denominadas como sociedades institucionais.

As institucionais são constituídas sob a forma de sociedades anônimas e sociedades em comandita por ações, enquanto as contratuais são constituídas nas demais formas societárias previstas em lei.

Por outro lado, as sociedades institucionais estão mais baseadas na perpetuação da atividade exercida e não tanto na affectio societatis existente entre os sócios que a compõem, tornando, portanto, seu desfazimento estrutural mais complexo.

\subsubsection{PELA RESPONSABILIDADE SOCIAL}

As sociedades empresárias, quando classificadas de acordo com sua responsabilidade social, podem ser sociedades empresárias de responsabilidade (a) limitada, ou seja, sociedades cuja responsabilidade patrimonial de seus sócios encontra-se limitada ao valor de suas contribuições (e.g. sociedades por ações) ou à integralização do capital social (e.g. sociedades limitadas), (b) ilimitada, ou seja, a responsabilidade patrimonial dos sócios pelas obrigações sociais será ilimitada e solidária (e.g. sociedades em nome coletivo) ou (c) mista, i.e., quando o contrato social estabelece que sócios gozam de responsabilidade limitada e que sócios estão sujeitos à responsabilidade ilimitada e solidária (e.g. sociedade em comandita simples, sociedades em comandita por ações).

No entanto, inclusive nas sociedades ilimitadas, a responsabilidade dos sócios será subsidiária ${ }^{25}$. Em suma, apenas se os bens da sociedade não forem suficientes para adimplir com as obrigações sociais, responderão os sócios pelo saldo remanescente, levando-se em consideração a proporção

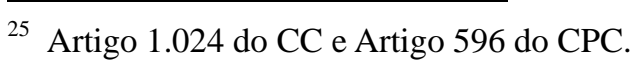


em que participa das perdas sociais, salvo cláusula de responsabilidade solidária.

\subsubsection{PELA COMPOSIÇÃO ECONÔMICA}

As sociedades empresárias podem, ainda, ser classificadas como sociedades (a) de pessoas ou (b) de capital, dependendo de sua composição econômica. As sociedades empresárias de pessoas são aquelas formadas em razão da qualidade pessoal dos sócios (e.g. sociedade em nome coletivo, sociedade em comandita simples, sociedade de capital e indústria), enquanto as sociedades de capital apresentam o capital social como elemento mais relevante em relação à pessoa dos sócios, sendo estes meros investidores (e.g. sociedade por ações). Em outras palavras, a sociedade independe de quem figure como sócio, pois estes podem mudar e a pessoa jurídica continua inalterada, tendo em vista não estar condicionada ao estado dos sócios e sim ao capital que detém.

\subsection{TIPOS SOCIETÁRIOS}

Quanto aos tipos societários, temos três divisões em relação ao uso destes pelas sociedades empresárias e simples, quais sejam: (a) tipos societários utilizados apenas por sociedades empresárias; (b) tipos societários utilizados apenas por sociedades simples; e (c) tipos societários que podem ser utilizados tanto por sociedades empresárias quanto por sociedades simples.

As sociedades institucionais, ou cujo capital seja divido em ações (i.e. sociedades anônimas e sociedades de comandita por ações) serão sempre empresárias, mesmo não havendo elemento de empresa em suas atividades, conforme parágrafo único do artigo 982 do CC. 
Por outro lado, as cooperativas, mesmo que com elemento de empresa em suas atividades, serão sempre sociedades simples, também conforme parágrafo único do artigo 982 do CC.

Finalmente, temos que os demais tipos societários (i.e. as sociedades em nome coletivo, em comandita simples e limitada) são tipos societários genuinamente empresários, mas nada impede que se prestem à constituição de sociedades simples ${ }^{26}$.

\section{Conforme leciona Fábio Ulhôa ${ }^{27}$ :}

“A sociedade anônima, também referida pela expressão "companhia”, é a sociedade empresária com capital social dividido em ações, espécie de valor mobiliário, na qual os sócios, chamados acionistas, respondem pelas obrigações sociais até o limite do preço de emissão das ações que possuem.”

Enquanto "A sociedade por quotas de responsabilidade limitada ou, simplesmente, sociedade limitada" ${ }^{28}$ é a sociedade empresária com o capital social dividido em quotas, na qual os sócios, respondem pelas obrigações sociais até o limite de sua participação integralizada no capital social, referida sociedade visa

\footnotetext{
"atender ao interesse de pequenos e médios empreendedores, que queriam beneficiar-se, na exploração de atividade econômica, da limitação da responsabilidade, típica das anônimas, mas sem atender às complexas formalidades destas, nem se sujeitar à prévia autorização governamental."28
}

Ainda, vale ressaltar que Sérgio Campinho ${ }^{29}$ diferencia a sociedade anônima da sociedade em comandita por ações da seguinte forma:

\footnotetext{
${ }^{26}$ Artigo 983 do CC.

${ }^{27}$ COELHO, Fábio Ulhôa. Curso de Direito Comercial. Vol. II. 9a ed. São Paulo: Saraiva, 2006. p 63.

${ }^{28}$ COELHO, Fábio Ulhôa. Curso de Direito Comercial. Vol. II. 9a ed. São Paulo: Saraiva, 2006. p 364.

${ }^{29}$ CAMPINHO, Sérgio. O Direito de Empresa à Luz do Novo Código Civil. $8^{\mathrm{a}}$ ed. Rio de J aneiro: Renovar, 2008. p 281 e 282.
} 
“(a) a sociedade adotará como nome empresarial firma ou denominação; (b) somente o sócio (acionista) tem qualidade para administrar a sociedade; (c) como diretor, o sócio responderá subsidiariamente e de forma ilimitada pelas obrigações sociais, contemporâneas à sua gestão, ao passo que os demais continuam a ter responsabilidade limitada ao preço de emissão das ações subscritas ou adquiridas; (d) se houver dois ou mais diretores, estabelecer-se-á a solidariedade entre eles, mas sempre condicionada ao esgotamento dos bens da sociedade; (e) a nomeação dos diretores se materializa no estatuto social; (f) o prazo de gestão é indeterminado; (g) a destituição do sócio-diretor somente se opera com a deliberação de acionista ou acionistas titulares de, no mínimo, 2/3 do capital social; (h) o diretor exonerado ou destituído continua, durante 2 anos, responsável pelas obrigações sociais contraídas sob a sua administração; (i) a assembléia não pode, sem o assentimento dos diretores, alterar o objeto essencial da sociedade, prorrogar-lhe o prazo de duração, aumentar ou reduzir o capital, criar debêntures ou partes beneficiárias”.

No que se refere às sociedades anônimas, temos que estas são disciplinadas pela Lei 6.404/76 (“LSA”), enquanto as sociedades limitadas são disciplinadas pelo CC em seus artigos 1.052 à 1.087. Adicionalmente, argumenta Fábio Ulhôa Coelho ${ }^{30}$ :

"Esse conjunto de normas, porém, não é suficiente para disciplinar a imensa gama de questões jurídicas relativas às limitadas. Outras disposições e diplomas legais, portanto, também se aplicam a este tipo societário.”

Portanto, onde houver omissão no capítulo que trata das sociedades limitadas no CC, aplicar-se-á, subsidiariamente, os dispositivos pertinentes às sociedades simples, ressalvado os casos onde for convencionado no contrato social a aplicação Lei das S.A. de forma supletiva.

${ }^{30}$ COELHO, Fábio Ulhôa. Manual de Direito Comercial. 15ª ed. São Paulo: Saraiva, 2004. p 153 e 154. 


\section{RESPONSABILIDADE PATRIMONIAL NAS SOCIEDADES EMPRESÁRIA}

\subsection{CONCEITO E ESPÉCIES}

Conforme exposto no item 2.7 (B) acima, as sociedades empresárias podem ser classificadas, conforme a limitação de sua responsabilidade patrimonial em: (a) limitadas, (b) ilimitadas, ou (c) mistas. Considerando que o objeto do presente estudo tem como foco as sociedades limitadas e as sociedades anônimas, incumbirá ao presente capítulo o estudo do instituto da responsabilidade limitada no direito brasileiro, em especial em relação aos referidos tipos societários.

No direito brasileiro, os sócios de uma sociedade empresária, em regra, têm responsabilidade patrimonial subsidiária no que se refere às obrigações assumidas pela sociedade. Isto ocorre devido à personalização das sociedades empresárias, por meio da qual estas passam a ser entes distintos de seus sócios, com patrimônio, direitos e obrigações próprios.

Conforme Fábio Ulhôa ${ }^{31}$ :

"Da definição da sociedade empresária como pessoa jurídica derivam conseqüências precisas, relacionadas com a atribuição de direitos e obrigações ao sujeito de direito nela encerrado. Em outros termos, na medida em que a lei estabelece a separação entre a pessoa jurídica e os membros que a compõem, consagrando o princípio da autonomia patrimonial. (...) Os bens integrantes do estabelecimento empresarial, e outros eventualmente atribuídos à pessoa jurídica, são de propriedade dela, e não dos seus membros. Não existe comunhão ou condomínio dos sócios relativamente aos bens sociais; sobre estes os componentes da sociedade empresária não exercem nenhum direito, de propriedade ou de outra natureza. É apenas a pessoa jurídica da sociedade a proprietária de tais bens. No patrimônio dos sócios, encontra-se a participação societária, representada pelas quotas da sociedade limitada ou pelas ações da sociedade anônima. A participação societária, no entanto, não se confunde com o conjunto de bens titularizados pela sociedade, nem com uma sua parcela ideal. Trata-se, definitivamente, de patrimônios distintos, inconfundíveis e incomunicáveis os dos sócios e o da sociedade.”

${ }^{31}$ COELHO, Fábio Ulhôa. Curso de Direito Comercial. Vol. II. 9a ed. São Paulo: Saraiva, 2006. p 13 e 14. 
Isso significa dizer que, enquanto não for exaurido todo o patrimônio social, não há de se falar em utilização do patrimônio dos sócios para satisfazer as obrigações da sociedade. Referido instituto é conhecido no direito comercial como Benefício de Ordem e encontra-se disciplinado nos artigo 1.024 do CC e 596 do CPC.

Outrossim, no direito brasileiro, não é regra a responsabilidade solidária entre os sócios e a sociedade, cabendo àqueles sempre o benefício de ordem executado através da indicação de bens sociais livres e desembaraçados à execução fruto do inadimplemento das obrigações sociais.

A responsabilidade solidária pode ser observada, excepcionalmente, entre os sócios em relação à obrigação de formação do capital social, mas nunca entre os sócios e a sociedade (e.g. artigo 1.052 do $\mathrm{CC}^{32}$ ).

A responsabilidade patrimonial dos sócios no âmbito das obrigações contraídas pela sociedade, além de subsidiária, pode ser limitada ou ilimitada. Isto significa dizer que, dependendo da situação e de determinadas condições, os sócios responderão ilimitadamente, i.e., pelo valor integral da dívida social remanescente após o esgotamento do patrimônio social, ou responderão pelas obrigações sociais de forma limitada, i.e., tendo como limite o valor do investimento realizado na sociedade.

Nesse sentido também leciona Fábio Ulhôa ${ }^{33}$ :

"Pelo terceiro critério de classificação das sociedades, estas podem ser de três categorias: a) a de responsabilidade ilimitada, se todos os sócios respondem pelas obrigações sociais ilimitadamente (sociedade em nome coletivo); b) as de responsabilidade mista, quando apenas parte dos sócios responde de forma ilimitada (sociedades em comandita simples ou por ações); e c) as de responsabilidade limitada, em que todos os sócios respondem de forma limitada pelas obrigações sociais (sociedades por quotas de responsabilidade limitada e anônima)."

\footnotetext{
32 Artigo 1.052 do CC.

${ }^{33}$ COELHO, Fábio Ulhôa. Curso de Direito Comercial. Vol. II. 9ª ed. São Paulo: Saraiva, 2006. p 28.
} 
A personalidade jurídica da sociedade empresária inicia-se a partir do registro do instrumento constitutivo perante a competente Junta Comercial $^{34}$, terminando com o procedimento dissolutório judicial ou extrajudicial da sociedade que se dividem em três fases, quais sejam: (a) dissolução, (b) liquidação e (c) partilha.

\subsection{DESCONSIDERAÇÃO DA PERSONALIDADE JURÍDICA}

Tendo em vista a possibilidade do uso dos institutos da autonomia e da limitação patrimonial das sociedades empresárias, ambos estudados acima, para fins fraudulentos ou de abuso de direito contra credores, a norma comercial seguiu no sentido de criar institutos hábeis a proteger os credores em tais casos. O mais relevante de tais institutos é o instituto da Desconsideração da Personalidade Jurídica, que surge para reparar os efeitos danosos causados aos credores pela manipulação da autonomia das pessoas jurídicas com fins fraudulentos ou de abuso de poder.

No direito brasileiro a Desconsideração da Personalidade Jurídica foi dividida em duas teorias. A primeira, conhecida como Teoria Maior da Desconsideração da Personalidade Jurídica, implica no afastamento episódico da autonomia patrimonial das pessoas jurídicas em razão da caracterização de manipulação fraudulenta ou abusiva da autonomia da pessoa jurídica, sendo, portanto, uma teoria mais consistente e abstrata. A segunda, conhecida como Teoria Menor da Desconsideração da Personalidade Jurídica, implica no afastamento da autonomia patrimonial das pessoas jurídicas, com base no simples inadimplemento de obrigação da sociedade e demonstração, por parte do credor, da ausência de patrimônio social hábil a satisfazer seu crédito e solvência do patrimônio dos sócios para tanto, tratando-se, assim, de uma teoria menos elaborada e mais objetiva.

\footnotetext{
${ }^{34}$ Artigo 45 do CC.
} 
Resumindo, a aplicação da teoria da desconsideração da personalidade jurídica não tem como conseqüência a despersonalização, a dissolução ou anulação da sociedade. Ocorre que, apenas, em caso específico, onde a autonomia patrimonial da sociedade tenha sido fraudulentamente utilizada ou utilizada com abuso de direito, referida autonomia patrimonial não será considerada, ou seja, a sua existência será desconsiderada para fins daqueles atos, tratando-se, portanto, de uma suspensão pontual de sua eficácia.

A característica episódica da desconsideração da personalidade jurídica é a principal diferença entre ela e os demais institutos desenvolvidos para coibir fraudes e abusos por meio de pessoas jurídicas, sendo possível coibir fraudes e abusos sem prejuízo dos trabalhadores, consumidores e outros afetados pela existência da pessoa jurídica.

\subsubsection{TEORIA MAIOR DA DESCONSIDERAÇÃO DA PERSONALIDADE JURÍDICA}

Na prática, tendo em vista o ordenamento jurídico brasileiro, a Teoria Maior da Desconsideração da Personalidade Jurídica depende da reunião de três elementos, quais sejam: (a) a insolvência de uma obrigação; (b) o abuso da personalidade jurídica da pessoa jurídica, por meio de desvio de finalidade ou confusão patrimonial, que servirá para não adimplir com a respectiva obrigação, conforme a regra geral exposta pelo artigo 50 do $\mathrm{CC}^{35}$; e (c) a inexistência de patrimônio social hábil a satisfazer a obrigação insolvida, tendo em vista o instituto do Benefício de Ordem, consagrado pelo disposto no artigo 1024 do CC.

\footnotetext{
${ }^{35}$ Artigo 50 do CC "Em caso de abuso da personalidade jurídica, caracterizado pelo desvio de finalidade, ou pela confusão patrimonial, pode o juiz decidir, a requerimento da parte, ou do Ministério Público quando lhe couber intervir no processo, que os efeitos de certas e determinadas relações de obrigações sejam estendidos aos bens particulares dos administradores ou sócios da pessoa jurídica.”.
} 
Outro exemplo da normativização da Teoria Maior da Desconsideração da Personalidade Jurídica, encontra-se no caput do artigo 28 da Lei 8.078/90 que instituiu o Código de Defesa do Consumidor $(\text { (“CDC") })^{36}$.

De acordo com entendimento do Superior Tribunal de Justiça $\left(\right.$ ("STJ") ${ }^{37}$

\begin{abstract}
“A teoria maior da desconsideração, regra geral no sistema jurídico brasileiro, não pode ser aplicada com a mera demonstração de estar a pessoa jurídica insolvente para o cumprimento de suas obrigações. Exige-se, aqui, para além da prova de insolvência, ou a demonstração de desvio de finalidade (teoria subjetiva da desconsideração), ou a demonstração de confusão patrimonial (teoria objetiva da desconsideração).”
\end{abstract}

Assim, temos que a aplicação da desconsideração da personalidade jurídica depende da personalidade jurídica autônoma da sociedade empresária ter sido utilizada como impedimento para a satisfação de uma obrigação não solvida, ou seja, a desconsideração da personalidade jurídica é o ato prévio a mudança na imputação de um ato lícito a sociedade para a imputação de um ato ilícito aos seus sócios ou administradores onde a sociedade terá sua personalidade jurídica desconsiderada justamente por esta ser um obstáculo à imputação do ato a outrem.

Nesse sentido, conclui-se, também, que, sendo o ilícito passível de imputação direta como ato de sócio ou administrador, não será caso de desconsideração da personalidade jurídica e sim de aplicação de outros institutos. Ainda nesse sentido, Fábio Ulhôa ${ }^{38}$ em sua obra exemplifica que:

“A responsabilização, por exemplo, do administrador de instituição financeira sob intervenção por atos de má administração faz-se independentemente da suspensão

${ }^{36}$ Caput do Artigo 28 do CDC “O juiz poderá desconsiderar a personalidade jurídica da sociedade quando, em detrimento do consumidor, houver abuso de direito, excesso de poder, infração da lei, fato ou ato ilícito ou violação dos estatutos ou contrato social. A desconsideração também será efetivada quando houver falência, estado de insolvência, encerramento ou inatividade da pessoa jurídica provocados por má administração.”.

${ }^{37}$ STJ, REsp n. 279273/SP, Rel. Ministro Ari Pargendler, 4 dez. 2003.

${ }^{38}$ COELHO, Fábio Ulhôa. Curso de Direito Comercial. Vol. II. 9a ed. São Paulo: Saraiva, 2006. p 43. 
da eficácia do ato constitutivo da sociedade. Ela independe, por assim dizer, da autonomia patrimonial da pessoa jurídica da instituição financeira. Tanto faz se a companhia bancária é considerada ou desconsiderada, a má administração é ato imputável ao administrador. É ele o direto responsável, porque administrou mal a sociedade; a obrigação é imputada a ele diretamente, sem o menor entrave, derivado da personalidade jurídica desta.”

\subsubsection{TEORIA MENOR DA DESCONSIDERAÇÃO DA PERSONALIDADE JURÍDICA}

Em relação à Teoria Menor da Desconsideração da Personalidade Jurídica, o sistema normativo pátrio tem como requisito para sua aplicação apenas a insolvência de obrigação da sociedade após exaurido o patrimônio social.

É possível encontrar a aplicação da referida teoria em dispositivos do ordenamento jurídico, tais como: (a) parágrafo 5 do artigo 28 do CDC $^{39}$; (b) artigo 4 da lei 9605/9840; e (c) artigo 18 Lei no. 8.884/94 ("Lei Antitruste" $)^{41}$. Ainda, vale ressaltar que existe controvérsia doutrinária e jurisprudencial sobre a aplicação desta teoria no âmbito trabalhista.

\section{Conforme Fábio Ulhôa:}

"De acordo com a teoria menor da desconsideração, se a sociedade não possui patrimônio, mas o sócio é solvente, isso basta para responsabilizá-lo por obrigações daquela. A formulação menor não se preocupa em distinguir a

39 Parágrafo 5 do artigo 28 do CDC “O juiz poderá desconsiderar a personalidade jurídica da sociedade quando, em detrimento do consumidor, houver abuso de direito, excesso de poder, infração da lei, fato ou ato ilícito ou violação dos estatutos ou contrato social. A desconsideração também será efetivada quando houver falência, estado de insolvência, encerramento ou inatividade da pessoa jurídica provocados por má administração. (...) Também poderá ser desconsiderada a pessoa jurídica sempre que sua personalidade for, de alguma forma, obstáculo ao ressarcimento de prejuízos causados aos consumidores.”.

40 Artigo 4 da lei 9605/98 "Poderá ser desconsiderada a pessoa jurídica sempre que sua personalidade for obstáculo ao ressarcimento de prejuízos causados à qualidade do meio ambiente.”.

41 Artigo 18 Lei no. 8.884/94 “A personalidade jurídica do responsável por infração da ordem econômica poderá ser desconsiderada quando houver da parte deste abuso de direito, excesso de poder, infração da lei, fato ou ato ilícito ou violação dos estatutos ou contrato social. A desconsideração também será efetivada quando houver falência, estado de insolvência, encerramento ou inatividade da pessoa jurídica provocados por má administração.”. 
utilização fraudulenta da regular do instituto, nem indaga se houve ou não abuso de forma.”. ${ }^{42}$

Ainda nesse sentido, conforme julgado do STJ:

\begin{abstract}
“A teoria menor da desconsideração, acolhida em nosso ordenamento jurídico excepcionalmente no Direito do Consumidor e no Direito Ambiental, incide com a mera prova de insolvência da pessoa jurídica para o pagamento de suas obrigações, independentemente da existência de desvio de finalidade ou de confusão patrimonial. Para a teoria menor, o risco empresarial normal às atividades econômicas não pode ser suportado pelo terceiro que contratou com a pessoa jurídica, mas pelos sócios e/ou administradores desta, ainda que estes demonstrem conduta administrativa proba, isto é, mesmo que não exista qualquer prova capaz de identificar conduta culposa ou dolosa por parte dos sócios e/ou administradores da pessoa jurídica.” 43
\end{abstract}

No entanto, existe uma corrente doutrinária que acredita que os dispositivos legais supracitados devem, de qualquer maneira, respeitar os requisitos da Teoria Maior da Desconsideração da Personalidade Jurídica. A teoria da desconsideração, como visto, tem pertinência apenas quando a responsabilidade não pode ser, em princípio, diretamente imputada ao sócio, controlador ou representante legal da pessoa jurídica. Se a imputação pode ser direta, se a existência da pessoa jurídica não é obstáculo à responsabilização de quem quer que seja, não há por que cogitar do superamento de sua autonomia e quando alguém, na qualidade de sócio, controlador ou representante legal da pessoa jurídica, provoca danos a terceiros, inclusive consumidores, em virtude de comportamento ilícito, responde pela indenização correspondente.

Entretanto, prevalece o entendimento expresso no acórdão supracitado de que tais dispositivos são aplicações legislativas práticas da Teoria Menor da Desconsideração da Personalidade Jurídica, conforme, por exemplo, o seguinte trecho de julgado do $\mathrm{STJ}^{44}$ :

\footnotetext{
${ }^{42}$ COELHO, Fábio Ulhôa. Curso de Direito Comercial. Vol. II. 9ª ed. São Paulo: Saraiva, 2006. p 46.

43 STJ, REsp n. 279273/SP, Rel. Ministro Ari Pargendler, 4 dez. 2003.

44 STJ, REsp n. 279273/SP, Rel. Ministro Ari Pargendler, 4 dez. 2003.
} 
“A aplicação da teoria menor da desconsideração às relações de consumo está calcada na exegese autônoma do $\S 5^{\circ}$ do art. 28, do CDC, porquanto a incidência desse dispositivo não se subordina à demonstração dos requisitos previstos no caput do artigo indicado, mas apenas à prova de causar, a mera existência da pessoa jurídica, obstáculo ao ressarcimento de prejuízos causados aos consumidores.”

\title{
Nesta mesma decisão, vota o Ministro Castro Filho ${ }^{45}$
}

\begin{abstract}
"Essa orientação, visualizando no referido preceito normativo hipótese objetiva de desconsideração da personalidade jurídica, encontra ressonância em outros diplomas legais, de que é exemplo a Lei no 9.605/98, versando sobre as "sanções penais e administrativas derivadas de condutas e atividades lesivas ao meio ambiente", cujo artigo $4^{\circ}$ assim dispõe: "Poderá ser desconsiderada a pessoa jurídica sempre que sua personalidade for obstáculo ao ressarcimento de prejuízos causados à qualidade do meio ambiente.” $\mathrm{Na}$ área do Direito do Trabalho, também existem decisões aplicando a teoria da despersonalização na execução de créditos trabalhistas, uma vez constatada a insuficiência do patrimônio societário para honrar tais compromissos.”
\end{abstract}

\section{Em outra decisão ${ }^{46}$ :}

“A proteção e defesa dos direitos do consumidor é de tal relevância, que, juntamente com o direito ambiental, tem a prerrogativa, dada pelo próprio ordenamento jurídico, de aplicação excepcional da Teoria Menor para fins de desconsideração da personalidade jurídica das sociedades empresárias. Para tal teoria, é possível a desconsideração da personalidade jurídica com a mera prova da insolvência da pessoa jurídica no adimplemento de suas obrigações, independentemente de comprovação de desvio de finalidade ou de confusão patrimonial. Tratando-se de demanda em que se discutem direitos ínsitos à relação de consumo, esgotando-se todos os mecanismos para a satisfação do direito de crédito já declarado em juízo, necessário o afastamento temporário da personalidade jurídica da sociedade empresária com o fim de alcançar o patrimônio de seus sócios, no sentido do efetivo cumprimento da sentença já exarada em regular processo de conhecimento. Conhecimento e provimento do recurso.”

${ }^{45}$ STJ, REsp n. 279273/SP, Rel. Ministro Ari Pargendler, 4 dez. 2003.

${ }^{46}$ TJRJ, Agrav. Inst. n. 2010.002.0161-6, Des. Rogério de Oliveira Souza, 9a Câmara Cível, Rio de Janeiro, 13 abr. 2010. 


\subsubsection{TEORIA INVERSA DA DESCONSIDERAÇÃO DA PERSONALIDADE JURÍDICA}

A Teoria da Desconsideração Inversa da Personalidade Jurídica visa coibir os casos onde o devedor, visando frustrar o direito do credor, transfere bens para o nome da pessoa jurídica de que absoluto controle, permanecendo, portanto, no pleno gozo dos referidos bens.

Um exemplo prático sobre a desconsideração inversa pode ser encontrada no direito de família, conforme ilustra Fábio Ulhôa ${ }^{47}$ quando leciona que

"A desconsideração invertida ampara, de forma especial, os direitos de família. Na desconstituição do vínculo de casamento ou de união estável, a partilha de bens comuns pode resultar fraudada. Se um dos cônjuges ou companheiros, ao adquirir bens de maior valor, registra-os em nome de pessoa jurídica sob seu controle, eles não integram, sob o ponto de vista formal, a massa a partilhar.”

${ }^{47}$ COELHO, Fábio Ulhôa. Curso de Direito Comercial. Vol. II. 9a ed. São Paulo: Saraiva, 2006. p 45. 


\section{ADMINISTRADORES}

\subsection{ADMINISTRADORES DAS SOCIEDADES ANÔNIMAS}

Nas sociedades anônimas o termo administradores abrange os membros que compõem dois dos órgãos da estrutura societária das companhias, quais sejam: (a) a diretoria; e (b) o conselho de administração.

Portanto, é correto afirmar que aos diretores e aos conselheiros aplicam-se as mesmas normas quanto aos requisitos, impedimentos, investidura, remuneração, deveres e responsabilidades ${ }^{48}$.

\subsubsection{REQUISITOS}

São requisitos legais expressos para a eleição de administradores das companhias: (a) ser pessoa natural; (b) ser residente no Brasil, salvo membros do conselho de administração que constitua procurador no Brasil; (c) ser acionista da companhia (apenas no caso de membros do conselho de administração); e (d) não estar impedido de exercer cargo de administração ${ }^{49}$.

Quanto ao item (a) acima, cabe comentar que a LSA estabeleceu tal requisito por questões operacionais, uma vez que os procedimentos de registro seriam mais complexos caso fosse permitida a eleição de uma pessoa jurídica como administradora de uma companhia, tendo em vista que esta deveria, por fim, indicar uma pessoa natural.

Em relação ao item (b) acima, o pertinente artigo da LSA foi elaborado com o espírito de que a presença do administrador no acompanhamento direto da empresa seria necessária para o correto desempenho das funções relativas à administração de uma companhia. Porém, é importante ressaltar que existe uma exceção para este requisito,

\footnotetext{
48 Artigo 145 da LSA

49 Artigo 146 da LSA
} 
qual seja: a possibilidade de eleição de membro do conselho de administração residente ou domiciliado no exterior, desde que este constitua procurador residente no Brasil $^{50}$.

Por fim, cabe ressaltar que o motivo de aplicabilidade do item (c) acima está relacionado à importância das atribuições impostas pela LSA aos conselheiros e aos diretores, sendo, portanto, mais seguro para a companhia que seus conselheiros sejam, também, acionistas desta.

\subsubsection{IMPEDIMENTOS}

Não poderão ser membros dos órgãos de administração de uma companhia as pessoas (a) impedidas por lei especial, (b) condenada pela prática de certos crimes (e.g. crime falimentar, de prevaricação, de suborno, de concussão, de peculato, contra a economia popular, contra a fé pública ou contra a propriedade), ou (c) que cumpram pena que vede, mesmo que em caráter temporário, o acesso a cargos, funções ou empregos públicos ${ }^{51}$.

Em se tratando de companhias de capital aberto, também estão impedidos de exercer funções de administradores aquelas pessoas declaradas inabilitadas por ato da Comissão de Valores Mobiliários (“CVM") 52 .

Da mesma maneira, estão impedidos de exercer a função de administradores nas companhias aquelas pessoas que não tenham reputação ilibada, que ocupem cargos em empresas concorrentes ou que tenham interesses conflitantes com os da companhia, salvo, nesses casos, se a assembléia geral da companhia não apresentar oposição, de forma $\operatorname{expressa}^{53}$.

\footnotetext{
50 Parágrafo $2^{\circ}$ do Artigo 146 da LSA.

51 Parágrafo $1^{\circ}$ do artigo 147 da LSA.

52 Parágrafo $2^{\circ}$ do artigo 147 da LSA.

53 Parágrafo $3^{\circ}$ do artigo 147 da LSA.
} 
O impedimento de eleição de pessoa que ocupa cargo em empresas concorrentes visa proteger a companhia de práticas desleais e que venham contra o interesse da companhia, tendo em vista possível vantagem a ser auferida à empresa concorrente em razão do poder dos administradores de tomar determinadas decisões e o acesso irrestrito às informações da companhia.

\subsubsection{INVESTIDURA}

A posse é requisito para a investidura do administrador em seu respectivo cargo, posse esta que deverá ocorrer no máximo em 30 dias após a data de eleição.

Não obstante, referido prazo poderá ser ultrapassado somente em casos considerados justificáveis pelos demais membros do órgão para o qual o administrador foi eleito.

A posse ocorre através da assinatura por parte do administrador de seu termo de posse específico que será lavrado no livro de atas do órgão para o qual foi eleito.

Nesse sentido encontram-se estabelecidas as regras dispostas no artigo 149 da $\mathrm{LSA}^{54}$.

\subsubsection{REMUNERAÇÃO}

É de competência da assembléia geral estabelecer o montante da remuneração dos administradores, seus benefícios e verbas de representação. A remuneração será definida em termos globais ou

\footnotetext{
${ }^{54}$ Artigo 149 da LSA "Os conselheiros e diretores serão investidos nos seus cargos mediante assinatura de termo de posse no livro de atas do conselho de administração ou da diretoria, conforme o caso. § $1^{0}$ Se o termo não for assinado nos 30 (trinta) dias seguintes à nomeação, esta tornar-se-á sem efeito, salvo justificação aceita pelo órgão da administração para o qual tiver sido eleito. $2^{\mathrm{O}} \mathrm{O}$ termo de posse deverá conter, sob pena de nulidade, a indicação de pelo menos um domicílio no qual o administrador receberá as citações e intimações em processos administrativos e judiciais relativos a atos de sua gestão, as quais reputar-se-ão cumpridas mediante entrega no domicílio indicado, o qual somente poderá ser alterado mediante comunicação por escrito à companhia.”.
} 
individuais e devem ser levados em consideração as responsabilidades do administrador, o tempo dedicado à companhia, a competência e reputação profissional do administrador e os níveis de mercado para a fixação da remuneração ${ }^{55}$.

Ainda, se a companhia garante, por meio de seu estatuto social, a distribuição obrigatória de dividendos aos acionistas de pelo menos vinte e cinco por cento do lucro líquido da companhia, será possível atribuir alguma participação aos administradores ${ }^{56}$. Trata-se de espécie de remuneração variável, com vistas a estimular o bom empenho dos administradores. No entanto, referida participação não poderá ser superior à décima parte dos resultados da companhia (observada, ainda, a preferência de que trata o artigo 190 da $\mathrm{LSA}^{57}$, sendo o recebimento da referida participação condicionado à distribuição dos dividendos obrigatórios no exercício).

\subsection{ADMINISTRADORES DAS SOCIEDADES LIMITADAS}

A administração das sociedades limitadas tem como órgão representativo a Diretoria. A Diretoria tem como função interna administrar a sociedade e como função externa manifestar a vontade da sociedade.

\footnotetext{
55 Artigo 152 da LSA.

56 Parágrafo primeiro do artigo 152 da LSA.

57 Artigo 190 da LSA “As participações estatutárias de empregados, administradores e partes beneficiárias serão determinadas, sucessivamente e nessa ordem, com base nos lucros que remanescerem depois de deduzida a participação anteriormente calculada. Parágrafo único. Aplica-se ao pagamento das participações dos administradores e das partes beneficiárias o disposto nos parágrafos do artigo 201. (...) Art. 201. A companhia somente pode pagar dividendos à conta de lucro líquido do exercício, de lucros acumulados e de reserva de lucros; e à conta de reserva de capital, no caso das ações preferenciais de que trata o $\S 5^{\circ}$ do artigo 17 . $\S$ $1^{\circ}$ A distribuição de dividendos com inobservância do disposto neste artigo implica responsabilidade solidária dos administradores e fiscais, que deverão repor à caixa social a importância distribuída, sem prejuízo da ação penal que no caso couber. § $2^{\circ}$ Os acionistas não são obrigados a restituir os dividendos que em boa-fé tenham recebido. Presume-se a má-fé quando os dividendos forem distribuídos sem o levantamento do balanço ou em desacordo com os resultados deste.”.
} 


\subsubsection{REQUISITOS}

Mesmo frente às omissões do CC, os requisitos para se tornar administrador de uma sociedade limitada são semelhantes aos requisitos aplicáveis aos administradores de uma sociedade anônima. Tal entendimento pode ser extraído da doutrina e jurisprudência pátrias, tendo como base o quanto disposto na Lei $\mathrm{n}^{\circ}$ 6.015/73 ("Lei de Registros Públicos”), na Instrução Normativa $n^{\circ} 98$ do Departamento Nacional de Registro do Comércio (“DNRC”) e no parágrafo $1^{\circ}$ do artigo $1.010^{58}$ do CC. Referidos requisitos são: (a) ser pessoa natural; (b) ser residente no Brasil (tendo em vista a exigência de documento de identificação e CPF para qualificação do mesmo); e (c) não estar impedido de exercer cargo de administração.

\subsubsection{IMPEDIMENTOS}

Considerando as omissões do CC nos artigos responsáveis por regular a disciplina das sociedades limitadas, aplica-se o parágrafo $1^{\circ}$ do artigo 1.011 do CC para o requisito mencionado no item (c) acima. Segundo tal dispositivo legal temos que os impedimentos aplicáveis à eleição dos administradores das sociedades limitadas são os mesmos que os aplicáveis às sociedades anônimas mencionados no primeiro parágrafo do item 4.1 (B) acima.

\footnotetext{
${ }^{58}$ Parágrafo primeiro do artigo 1.011 do CC "Não podem ser administradores, além das pessoas impedidas por lei especial, os condenados a pena que vede, ainda que temporariamente, o acesso a cargos públicos; ou por crime falimentar, de prevaricação, peita ou suborno, concussão, peculato; ou contra a economia popular, contra o sistema financeiro nacional, contra as normas de defesa da concorrência, contra as relações de consumo, a fé pública ou a propriedade, enquanto perdurarem os efeitos da condenação.”.
} 


\subsubsection{INVESTIDURA}

Os administradores serão escolhidos pela maioria societária qualificada, variando o quorum necessário para sua eleição de acordo com a qualidade de sócio ou não do administrar perante a companhia e de acordo com o instrumento de designação, i.e., se por contrato social ou ato apartado. Nesse sentido, temos que o administrador sócio que for nomeado em contrato social deverá ser eleito por sócios detentores de três quartos do capital social da sociedade, tendo em vista se tratar, também, do quorum para modificar o ato constitutivo ${ }^{59}$. Por outro lado, o administrador designado por meio de ato apartado deverá ser eleito por mais da metade do capital $^{60}$. Por fim, o administrador não sócio somente poderá ser eleito se autorizada a eleição de administradores não sócios no contrato social da sociedade e deverá ser eleito, sempre, (a) pela unanimidade dos sócios, caso o capital social da sociedade não esteja integralizado, ou (b) por sócios detentores de dois terços do capital social da sociedade, caso o capital social da sociedade esteja integralizado ${ }^{61}$.

A investidura no cargo de administrador somente ocorrerá após a posse, que se da pela assinatura do pertinente termo de posse no livro de atas da administração. O prazo para a assinatura do referido termo é de trinta dias contados da designação do administrador pela sociedade. Ainda, dez dias após a investidura do administrador, este deverá requerer que seja averbada sua nomeação perante a Junta Comercial competente ${ }^{62}$.

O administrador pode ser eleito por prazo determinado ou indeterminado. Quando se tratar de prazo determinado, findo tal prazo o administrador precisará renovar o mandato ou deverá ser substituído.

\footnotetext{
59 Artigo 1.076, I do CC.

60 Artigo 1.076, II do CC.

${ }^{61}$ Artigo 1.061 do CC.

${ }^{62}$ Artigo 1.062 do CC.
} 
Outrossim, tenha sido o administrador eleito por prazo determinado ou por prazo indeterminado, os sócios poderão destituí-lo a qualquer tempo ${ }^{63}$.

\subsubsection{REMUNERAÇÃO}

Novamente em razão das omissões do CC quanto ao tema, seja quanto às sociedades limitadas ou quanto às sociedades simples, a remuneração poderá ser pactuada entre os sócios e os administradores sem, obrigatoriamente, estar sujeita a alguma formalidade, como seria o caso das sociedades anônimas, por exemplo.

${ }^{63}$ Artigo 1.063 do CC. 


\section{RESPONSABILIDADE DOS ADMINISTRADORES NAS SOCIEDADES EMPRESÁRIAS}

Este capítulo representa o objeto principal da presente monografia e tratará das hipóteses de responsabilização dos administradores tanto nas sociedades anônimas, quanto nas sociedades limitadas, seja de acordo com a LSA, com o CC ou com outros dispositivos legais aplicáveis.

Inicialmente, cabe ressaltar que as sociedades limitadas podem ser regidas supletivamente pela LSA frente à omissão de norma do CC no âmbito das sociedades limitadas (desde que expressamente previsto no contrato social) ${ }^{64}$. Caso contrário, também na omissão do CC, as sociedades limitadas serão regidas pelas normas referentes às sociedades simples.

Portanto, ratifica-se que algumas das hipóteses de responsabilização dos administradores das sociedades anônimas, poderão, nos casos de regência supletiva das sociedades limitadas pela LSA, vir a serem aplicadas no âmbito das sociedades limitadas.

A regra para a responsabilização do administrador é a de que o administrador somente será responsável pelos atos praticados com culpa ou dolo e/ou em desobediência à lei e/ou ao contrato/estatuto social, não devendo ser responsabilizado pelo mero prejuízo sofrido pela sociedade/companhia quando agiu nos limites de suas funções, com cuidado e diligência, tendo como objetivo alcançar os fins sociais.

Com base nessa regra, foram incorporadas ao nosso sistema jurídico as hipóteses de responsabilização do administrador que seguem.

\footnotetext{
${ }^{64}$ Artigo 1.053 do CC.
} 


\title{
5.1. RESPONSABILIDADE SOCIEDADES LIMITADAS
}

\author{
Conforme explica Tarsis Sarlo Gorge:
}

"fica configurada a responsabilidade do administrador de forma solidária com a Sociedade Administrada e ainda ilimitada quando agir com excesso de mandato ou violação do contrato ou da lei. Os administradores estão jungidos aos deveres de lealdade, boa-fé, fidelidade, em relação à sociedade que administram. Assim, quando desatendem a tais deveres, nasce a responsabilidade (Código Civil arts. 1011, 1016 e 1.017). Os atos ou omissões do administrador que tenham gerado prejuízos (danos emergentes e lucros cessantes) para a sociedade deverão ser pelo mesmo ressarcidos.” 65

\subsubsection{RESPONSABILIDADE PESSOAL E SOLIDÁRIA}

Os administradores das sociedades limitadas respondem de forma solidária pelos danos causados à sociedade e a terceiros, quando, por culpa no desempenho de suas funções, a sociedade e/ou terceiros vierem a ser prejudicados ${ }^{66}$.

Cabe ressaltar a natureza subjetiva da responsabilização do administrador nessa hipótese, sendo necessário, para tanto, provar que (a) o administrador agiu com culpa; (b) o administrador causou danos a sociedade ou a terceiros; e (c) existiu um nexo causal entre sua atuação culposa no exercício de suas funções e os danos sofridos pela sociedade e/ou por terceiros.

Em outras palavras, não basta que o administrador, agindo nos limites de suas funções, em conformidade com a lei e com o contrato social, tenha causado prejuízo a sociedade para que este venha a ser responsabilizado.

\footnotetext{
${ }^{65}$ JORGE, Tarsis Nametala Sarlo Jorge. Manual das Sociedades Limitadas.1 $1^{\mathrm{a}}$ ed. Rio de Janeiro: Lumen Júris, 2007. p 292.

${ }^{66}$ Artigo 1.016 do CC.
} 


\subsubsection{RESPONSABILIDADE ANTES DA AVERBAÇÃO DO ATO DE NOMEAÇÃO}

O administrador de uma sociedade limitada que, nomeado por instrumento em separado, não averbá-lo a margem da inscrição da sociedade, será responsabilizado pessoal e solidariamente pelos atos que praticar antes de requerer a referida averbação ${ }^{67}$.

Nesse caso, tanto os atos regulares quanto os atos irregulares praticados pelo administrador que vieram a trazer prejuízo à sociedade e/ou a terceiros serão de responsabilidade do administrador, uma vez que a averbação do instrumento de nomeação a margem da inscrição da sociedade é requisito para que se passe a considerar que o administrador está agindo em nome da sociedade, caso contrário, em outras palavras, todo e qualquer ato tomado pelo administrador será tido como ato que não foi tomado em nome da sociedade, sendo, portanto, de total responsabilidade do administrador ou dos administradores envolvidos.

\subsubsection{DEVERES DE CUIDADO E DILIGÊNCIA}

É dever do administrador das sociedades limitada ter cuidado e diligência no exercício das suas tarefas ${ }^{68}$.

Trata-se, de um dever subjetivo uma vez que o dever de cuidado e diligência apresenta como parâmetro o exercício que um homem de negócios ativo e probo teria.

Basicamente, os administradores têm o dever de fazer uso de técnicas adequadas à ciência da administração. No entanto, cabe ressalvar que se trata de uma obrigação de meio e não de resultado, ou seja, o administrador deverá aplicar as melhores técnicas da ciência da administração em razão dos fins sociais, mas não será responsabilizado caso

\footnotetext{
67 Artigo 1.012 do CC.

${ }^{68}$ Artigo 1.011 do CC.
} 
os fins sociais não sejam alcançados, sendo responsabilizado, apenas, por não atuar com cuidado e diligência nos termos acima expostos.

\subsubsection{DEVER DE ATUAR DE ACORDO A COM MAIORIA DOS VOTOS DOS SÓcIOS}

Nas sociedades limitadas, responderá por perdas e danos o administrador que realizar operações sabendo (ou devendo saber) que a realização destas vai de encontro com a decisão da maioria do capital votante, pois é dever do administrador atuar em nome da sociedade e de acordo com o interesse desta, que é, via de regra, exteriorizado por meio das decisões tomadas pelos órgãos decisórios ou administrativos das sociedades.

Nesse sentido, é clara a regra do artigo 1.013 do CC:

"A administração da sociedade, nada dispondo o contrato social, compete separadamente a cada um dos sócios.

$\S 1 \underline{\text { o }}$ Se a administração competir separadamente a vários administradores, cada um pode impugnar operação pretendida por outro, cabendo a decisão aos sócios, por maioria de votos.

$\S 2 \underline{\text { o }}$ Responde por perdas e danos perante a sociedade o administrador que realizar operações, sabendo ou devendo saber que estava agindo em desacordo com a maioria."

\subsubsection{EXCESSO NO EXERCÍCIO DO CARGO DE ADMINISTRADOR}

Os administradores das sociedades limitadas, conforme dispõem o artigo 1.015 do $\mathrm{CC}^{69}$, tem a liberdade de praticar todos os atos pertinentes à gestão da sociedade quando não limitados por disposição do contrato social.

69 Artigo 1.015 do CC "No silêncio do contrato, os administradores podem praticar todos os atos pertinentes à gestão da sociedade; não constituindo objeto social, a oneração ou a venda de bens imóveis depende do que a maioria dos sócios decidir.

Parágrafo único. O excesso por parte dos administradores somente pode ser oposto a terceiros se ocorrer pelo menos uma das seguintes hipóteses:

I - se a limitação de poderes estiver inscrita ou averbada no registro próprio da sociedade;

II - provando-se que era conhecida do terceiro;

III - tratando-se de operação evidentemente estranha aos negócios da sociedade.”. 
As limitações para atuação do administrador serão sempre impostas pela lei ou pelo contrato social, inclusive os casos onde terceiros podem apresentar resistência frente a alguns atos dos administradores estão elencados em lei, nos incisos do referido artigo 1.015 do CC, quais sejam: (a) os poderes de gestão apresentem limitação inscrita e averbada no registro da sociedade; (b) seja de conhecimento do terceiro que o administrador está agindo com excesso; e (c) seja observada operações evidentemente estranhas aos negócios da sociedade.

Assim, temos que a sociedade limitada não responderá pelos atos praticados por seus administradores em seu nome quando estes forem estranhos ao objeto social ou aos negócios que ela costuma desenvolver ou quando os administradores da sociedade agir em desobediência às limitações impostas aos mesmos por lei ou pelo contrato social. Esses atos contrários à lei, ao contrato social ou ao objeto social da sociedade são chamados de atos ultra vires.

A teoria dos atos ultra vires, conforme explica Tarsis Sarlo Gorge, é a teoria

"concebida para aportar critérios de responsabilidade das corporações ou de seus dirigentes quando houver violação do objeto social. Assim, os atos ultra vires podem ser considerados sob a perspectiva da sociedade (ultra vires the company) ou sob o ponto de vista do administrador (ultra vires the agent). No primeiro caso, há atos praticados além do objeto social fixado no estatuto ou contrato, enquanto no segundo caso, o ato é praticado em nome da sociedade e dentro do objeto social da empresa, mas alem dos poderes estatutários do dirigente.”70.

\subsubsection{RESPONSABILIDADE POR ATOS EM BENEFÍCIO PRÓPRIO OU DE TERCEIROS}

O administrador de uma sociedade limitada que aplicar créditos ou bens sociais em proveito próprio ou de terceiros, sem consentimento por escrito dos sócios da sociedade, terá de restituir tais créditos ou bens sociais

\footnotetext{
${ }^{70}$ JORGE, Tarsis Nametala Sarlo Jorge. Manual das Sociedades Limitadas. $1^{\mathrm{a}}$ ed. Rio de Janeiro: Lumen Júris, 2007. p 295.
} 
à sociedade ou restituir à sociedade a quantia equivalente, incluindo em tal quantia os lucros resultantes e qualquer prejuízo sofrido pela sociedade, conforme disposto pelo artigo 1.017 do $\mathrm{CC}^{71}$.

Também nesse sentido, nos termos do parágrafo único do referido dispositivo legal, fica sujeito às mesmas sanções o administrador que tome parte de deliberação tendo interesse contrário ao da sociedade.

\subsubsection{RESPONSABILIDADE POR DISTRIBUIÇÃO IRREGULAR DE DIVIDENDOS}

Com relação aos administradores das sociedades limitadas, não há regra expressa sobre sua responsabilidade em caso de distribuição fictícia de lucros, portanto, é necessário reportar-se às regras da sociedade simples, mais precisamente ao artigo 1.009 CC. Referido artigo dispõem que

\footnotetext{
"A distribuição de lucros ilícitos ou fictícios acarreta responsabilidade solidária dos administradores que a realizarem e dos sócios que os receberem, conhecendo ou devendo conhecer-lhes a ilegitimidade.”
}

Trata-se, portanto, de hipótese onde os lucros foram formalmente lançados no balanço apresentado, mas este balanço apresenta vícios em suas contas ou ocorreu alteração superveniente em relação à situação patrimonial da sociedade que tornou, naquele momento, a deliberação de distribuição de lucros inválida.

Assim, os administradores que distribuíram os lucros e os sócios que os receberam serão responsáveis por devolver à sociedade a quantia pertinente.

\footnotetext{
71 Artigo 1.017 do CC "O administrador que, sem consentimento escrito dos sócios, aplicar créditos ou bens sociais em proveito próprio ou de terceiros, terá de restituí-los à sociedade, ou pagar o equivalente, com todos os lucros resultantes, e, se houver prejuízo, por ele também responderá.

Parágrafo único. Fica sujeito às sanções o administrador que, tendo em qualquer operação interesse contrário ao da sociedade, tome parte na correspondente deliberação.”.
} 


\subsection{RESPONSABILIDADE} SOCIEDADES ANÔNIMAS

\subsubsection{RESPONSABILIDADE PESSOAL E SOLIDÁRIA}

A LSA estabelece como regra que "o administrador não é pessoalmente responsável pelas obrigações que contrai em nome da sociedade e em virtude de ato regular de gestão"72.

Porém, existem duas exceções para tal regra, quais sejam: (a) quando os administradores causarem prejuízo à companhia por meio de atos praticados com culpa ou dolo; e (b) quando os administradores extrapolarem suas atribuições ou poderes, seja em relação às atribuições legais ou estatutárias.

Quanto ao item (a) acima, faz-se necessário a comprovação de três elementos para sua caracterização, quais sejam: (i) culpa ou dolo (elemento subjetivo); (b) prejuízo sofrido pela companhia, acionistas ou terceiros; e (c) nexo causal entre a conduta culposa ou dolosa do administrador e o prejuízo causado. Em outras palavras, trata-se de uma hipótese de responsabilidade subjetiva do administrador.

Em relação ao item (b) acima, não há necessidade de observância do elemento culpa/dolo, ou seja, trata-se de responsabilidade objetiva lastreada, apenas, na violação das atribuições legais ou estatutárias conferidas aos administradores.

Neste sentido, leciona Darcy Arruda Miranda Junior:

\footnotetext{
"Distingue a norma legal dois tipos de atos que podem dar fundamento a responsabilidade civil do administrador: quando ele age, dentro de suas atribuições, com dolo ou culpa, e quando infringe disposição legal ou estatutária. No primeiro caso, cumpre provar que ele agiu culposa ou dolosamente, no segundo não, porque nem a lei nem os estatutos podem alegar desconhecer»73.

72 Artigo 158 da LSA.

73 JUNIOR, Darcy Arruda Miranda. Breves Comentários à Lei de Sociedades por Ações. $1^{\mathrm{a}}$ ed. São Paulo: Saraiva, 1977, p. 224.
} 
Conseqüentemente, não será responsabilizado o administrador que não for conivente, não for negligente, ou que agir para impedir a prática do ato ilícito, bem como não será responsável o administrador contrário ao exercício do ato ilícito, sendo necessário, para tanto, que a divergência seja expressamente informada para o pertinente órgão da administração, conselho fiscal ou assembléia geral (e.g. consignação em ata de reunião do pertinente órgão de administração da dissidência quando à pratica do ato ilícito).

Porém, violando esta responsabilidade, os administradores serão solidariamente responsáveis pelos prejuízos que causarem em virtude do descumprimento dos deveres impostos por lei a eles para fins de garantia do funcionamento normal da companhia.

Caso trate-se de violação à obrigação legal, todos os administradores envolvidos serão solidariamente responsáveis, inclusive aqueles que o estatuto social da companhia não incuba com as mesmas funções.

Não obstante a regra mencionada no parágrafo acima, tratando-se de companhias abertas, a responsabilidade por violação de obrigação legal ficará restrita aos administradores que tenham atribuição específica para dar cumprimento àqueles deveres.

Ainda, o administrador que tenha conhecimento do descumprimento destes deveres pelo administrador predecessor ou pelo administrador apontado como competente pelo estatuto social (no caso de companhias abertas) e não informar a respeito à assembléia geral, tornar-se, por tal descumprimento, solidariamente responsável.

Por fim, da mesma maneira, responderá solidariamente o administrador que concorrer com outro administrador que violou o estatuto social ou a lei para obter vantagem para si ou para outrem. 
Nesse sentido, explica Fábio Ulhôa ${ }^{74}$ que:

"No meu modo de ver a questão, contudo, é subjetiva do tipo clássico a natureza da responsabilidade prescrita pelo art. 158, II, da LSA, como também, por uma interpretação sistemática dos dispositivos legais sobre o assunto, é subjetiva a responsabilidade do administrador de instituição financeira, mesmo nas hipóteses de intervenção, liquidação extrajudicial, falência ou regime especial de administração temporária.”

\title{
5.2.2. DEVER DE DILIGÊNCIA
}

Conforme a regra do artigo 153 da $\mathrm{LSA}^{75}$, é dever do administrador da sociedade anônima ter cuidado e diligência no exercício das suas tarefas. Trata-se, portanto, de um dever subjetivo igual ao mencionado no item 5.1.3. acima.

Quanto às sociedades anônimas, temos que

\begin{abstract}
"O administrador, em outros termos, tem o dever de empregar certas técnicas aceitas como adequadas pela "ciência" da administração - na condução dos negócios sociais, tendo em vista a realização dos fins da empresa. Mas ele não responde pela efetiva realização dos fins sociais, sujeitos também à implementação de várias outras condições não inteiramente controláveis pela administração societária. A pesquisa jurídica sobre a incidência da norma do art. 153 da LSA, em determinado caso, não precisa e não deve ultrapassar os limites da apreciação técnica pertinente ao cumprimento da obrigação de meio."76
\end{abstract}

Esse instituto nasce de um instituto norte americano conhecido como business judgement rule, que estabelece que o administrador que atuar com certa racionalidade e técnica, tendo em vista as informações a ele disponibilizadas, não poderá ser responsabilizado por resultados negativos da companhia ${ }^{77}$.

\footnotetext{
${ }^{74}$ COELHO, Fábio Ulhôa. Curso de Direito Comercial. Vol. II. 9ª ed. São Paulo: Saraiva, 2006. p 250.

75 Artigo 153 da LSA.

${ }^{76}$ COELHO, Fábio Ulhôa. Curso de Direito Comercial. Vol. II. 9a ed. São Paulo: Saraiva, 2006. p 244.

77 NETTO, Nelson Rodrigues. Responsabilidade Civil dos Administradores das Sociedades Anônimas. Revista Forense. Vol. 358. p 141 e 142.
} 
Ainda, além da natureza de obrigação de meio e da necessidade do exercício da administração de maneira técnica, vem o artigo 154 da LSA exigir que, dentro do dever de diligência, as funções dos administradores sejam exercidas visando os interesses da companhia, principalmente visando satisfazer os fins sociais da companhia.

\subsubsection{RESPONSABILIDADE POR DESVIO DE FINALIDADE E ATRIBUIÇÕES}

Nas sociedades anônimas, conforme artigo 154 da $\operatorname{LSA}^{78}$, “ $O$ administrador deve exercer as atribuições que a lei e o estatuto lhe conferem para lograr os fins e no interesse da companhia, satisfeitas as exigências do bem público e da função social da empresa”, sendo vetado ao administrador, conforme parágrafo segundo do referido dispositivo legal: (a) faltar com seus deveres de administrador, mesmo que para defesa da classe ou grupo de acionistas que o elegeu; e conforme seu parágrafo segundo, (b) praticar ato de liberalidade à custa da companhia, (c) tomar por empréstimo recursos ou bens da companhia, ou usar, em proveito próprio, de sociedade em que tenha interesse, ou de terceiros, os seus bens, serviços ou crédito, sem prévia autorização da assembléia-geral ou do

78 Artigo 154 da LSA “O administrador deve exercer as atribuições que a lei e o estatuto lhe conferem para lograr os fins e no interesse da companhia, satisfeitas as exigências do bem público e da função social da empresa.

$\S 1^{\circ} \mathrm{O}$ administrador eleito por grupo ou classe de acionistas tem, para com a companhia, os mesmos deveres que os demais, não podendo, ainda que para defesa do interesse dos que o elegeram, faltar a esses deveres.

$\S 2^{\circ}$ É vedado ao administrador:

a) praticar ato de liberalidade à custa da companhia;

b) sem prévia autorização da assembléia-geral ou do conselho de administração, tomar por empréstimo recursos ou bens da companhia, ou usar, em proveito próprio, de sociedade em que tenha interesse, ou de terceiros, os seus bens, serviços ou crédito;

c) receber de terceiros, sem autorização estatutária ou da assembléia-geral, qualquer modalidade de vantagem pessoal, direta ou indireta, em razão do exercício de seu cargo.

$\S 3^{\circ}$ As importâncias recebidas com infração ao disposto na alínea c do $\S 2^{\circ}$ pertencerão à companhia.

$\S 4^{\circ} \mathrm{O}$ conselho de administração ou a diretoria podem autorizar a prática de atos gratuitos razoáveis em benefício dos empregados ou da comunidade de que participe a empresa, tendo em vista suas responsabilidades sociais.” 
conselho de administração, e (d) receber de terceiros qualquer modalidade de vantagem pessoal, direta ou indireta, em razão do exercício de seu cargo, sem autorização estatutária ou da assembléia geral.

Em caso de violação das disposições do parágrafo segundo mencionadas acima, pertencerão à companhia as importâncias recebidas pelos administradores ao cometer tais infrações.

Quanto ao item (a) acima, por exemplo, comenta Fábio Ulhôa Coelho ${ }^{79}$ :

"Especificamente, estabelece a lei a seguinte série de condutas proibidas: o administrador não pode privilegiar o grupo ou classe de acionistas que o elegeu; não pode incorrer em liberalidade à custa da companhia, admitida apenas a prática de atos gratuitos razoáveis em favor de empregados ou da comunidade, quando autorizado pelo conselho de administração ou pela diretoria; não pode, sem prévia autorização da assembléia geral ou do conselho de administração, tomar por empréstimo recursos ou bens da companhia, nem usar - em benefício próprio ou de outrem - seus bens, serviços e crédito; e não pode, por fim, sem autorização estatutária ou assemblear, receber de terceiros vantagem de qualquer tipo em razão do seu cargo.”

O ideal por traz desta hipótese de responsabilização do administrador é evitar que o administrador faça uso das atribuições que tem em razão do cargo que ocupa na companhia para obter vantagem indevida, para si ou para terceiros, por meio de atos que fogem aos fins sociais ou escapam de suas atribuições legais e/ou estatutárias.

\subsubsection{DEVER DE LEALDADE}

O conjunto de deveres conhecido como dever de lealdade do administrador está disposto no artigo 155 da LSA ${ }^{80}$. Segundo tal conjunto

${ }^{79}$ COELHO, Fábio Ulhôa. Curso de Direito Comercial. Vol. II. 9a ed. São Paulo: Saraiva, 2006. p 245.

${ }^{80}$ Artigo 155 da LSA "O administrador deve servir com lealdade à companhia e manter reserva sobre os seus negócios, sendo-lhe vedado:

I - usar, em benefício próprio ou de outrem, com ou sem prejuízo para a companhia, as oportunidades comerciais de que tenha conhecimento em razão do exercício de seu cargo; 
de deveres, o administrador deverá servir à companhia com lealdade e manter sigilo sobre seus negócios. Nesse sentido, foi vedado ao administrador: (a) em qualquer caso, fazer uso das oportunidades comerciais de que tenha conhecimento em razão do cargo de administrador da companhia; (b) omitir-se no exercício ou proteção de direitos da companhia, incluindo deixar de aproveitar oportunidades de negócios que sejam de interesse da companhia; e (c) adquirir bem ou direito que sabe ser necessário à companhia ou que a companhia pretenda adquirir, para revender com fins lucrativos.

Além disso, nas companhias abertas, é dever do administrador manter sigilo sobre as informações que este venha a ter conhecimento em razão do cargo que ocupa (informações estas ainda não divulgadas ao mercado e capazes de influenciar de a cotação de valores mobiliários), sendo, também, vedado ao administrador fazer uso destas informações para obter vantagem por meio da compra ou venda de valore mobiliários.

Ainda nesse sentido, o administrador deverá zelar para que tal violação também não ocorra por meio de subordinados ou terceiros de sua confiança.

II - omitir-se no exercício ou proteção de direitos da companhia ou, visando à obtenção de vantagens, para si ou para outrem, deixar de aproveitar oportunidades de negócio de interesse da companhia;

III - adquirir, para revender com lucro, bem ou direito que sabe necessário à companhia, ou que esta tencione adquirir.

$\S 1^{\circ}$ Cumpre, ademais, ao administrador de companhia aberta, guardar sigilo sobre qualquer informação que ainda não tenha sido divulgada para conhecimento do mercado, obtida em razão do cargo e capaz de influir de modo ponderável na cotação de valores mobiliários, sendo-lhe vedado valer-se da informação para obter, para si ou para outrem, vantagem mediante compra ou venda de valores mobiliários.

$\S 2^{\circ} \mathrm{O}$ administrador deve zelar para que a violação do disposto no $\S 1^{\circ}$ não possa ocorrer através de subordinados ou terceiros de sua confiança.

$\S 3^{\circ}$ A pessoa prejudicada em compra e venda de valores mobiliários, contratada com infração do disposto nos $\S \S 1^{\circ}$ e $2^{\circ}$, tem direito de haver do infrator indenização por perdas e danos, a menos que ao contratar já conhecesse a informação.

$\S 4^{\underline{0}}$ É vedada a utilização de informação relevante ainda não divulgada, por qualquer pessoa que a ela tenha tido acesso, com a finalidade de auferir vantagem, para si ou para outrem, no mercado de valores mobiliários.”. 
Como conseqüência ao acima exposto, o parágrafo terceiro do artigo em discussão dispõem que

\begin{abstract}
“A pessoa prejudicada em compra e venda de valores mobiliários, contratada com infração do disposto nos $\S \S 1^{\circ}$ e $2^{\circ}$, tem direito de haver do infrator indenização por perdas e danos, a menos que ao contratar já conhecesse a informação.”.
\end{abstract}

Por fim, nenhuma pessoa poderá utilizar informação relevante ainda não divulgada ao mercado, visando auferir qualquer vantagem no mercado de valores mobiliários, para si ou para outrem.

A violação a este conjunto de deveres é conhecido na doutrina como Insider Trading e está relacionada ao quanto disposto nos parágrafos $1^{\circ}$ ao $4^{\circ}$ do artigo 155 da LSA.

O insider é a pessoa interna da companhia que tem acesso às informações privilegiadas, não divulgadas ao mercado, capazes de influenciar de a cotação de valores mobiliários e Insider Trading, conforme leciona Modesto Carvalhosa, é o

"uso da informação relevante não divulgada na compra e venda de valore mobiliários de emissão da companhia, gerando um desequilíbrio de posições, lesivo tanto a uma das partes da operação - o comprador ou vendedor outsider - como ao próprio mercado de capitais, em termo de confiabilidade" ${ }^{81}$.

\title{
5.2.5. RESPONSABILIDADE POR CONFLITO DE INTERESSE
}

Na sociedade anônima, de acordo com o disposto no artigo 156 da LSA,

“é vedado ao administrador intervir em qualquer operação social em que tiver interesse conflitante com o da companhia, bem como na deliberação que a respeito tomarem os demais administradores, cumprindo-lhe cientificá-los do seu impedimento e fazer consignar, em ata de reunião do conselho de administração ou da diretoria, a natureza e extensão do seu interesse.”.

${ }^{81}$ CARVALHOSA, Modesto. Comentários à Lei de Sociedades Anônimas. Vol. $3^{\circ} .4^{\mathrm{a}}$ ed. São Paulo: Saraiva, 2009. p 311. 
Ainda, é proibido ao administrador de sociedade anônima contratar com a companhia em condições que não sejam razoáveis, eqüitativas e idênticas às que prevalecem no mercado ou às que a companhia contrataria com terceiros. No entanto, em caso de violação a esta proibição, o negócio contratado será considerado anulável e as vantagens recebidas pelo administrador deverão ser transferidas à companhia. Referida proibição e a respectiva conseqüência encontram-se dispostas nos parágrafos $1^{\circ}$ e $2^{\circ}$ do artigo 156 da LSA ${ }^{82}$.

Por fim, não pode o administrador da sociedade anônima favorecer sociedade coligada, controladora ou controlada, em prejuízo da companhia $^{83}$. Nesse caso, é dever do administrador proteger as operações que vierem a ser realizadas entre as sociedades de forma que estas ocorram de maneira comutativa ou mediante o pertinente pagamento compensatório, respondendo perante a companhia pelas perdas e danos resultantes de tal infração.

\subsubsection{DEVER DE INFORMAÇÃO AO MERCADO}

Trata-se de um importante dever imposto aos administradores das companhias de capital aberto. Quanto ao tema, explica Modesto Carvalhosa:

"O dever de informar dos administradores corresponde ao direito de ser informado dos acionistas em geral e dos acionistas minoritários em especial. Tal

\footnotetext{
${ }^{82}$ Artigo 156 da LSA "É vedado ao administrador intervir em qualquer operação social em que tiver interesse conflitante com o da companhia, bem como na deliberação que a respeito tomarem os demais administradores, cumprindo-lhe cientificá-los do seu impedimento e fazer consignar, em ata de reunião do conselho de administração ou da diretoria, a natureza e extensão do seu interesse.

$\S 1^{\circ}$ Ainda que observado o disposto neste artigo, o administrador somente pode contratar com a companhia em condições razoáveis ou eqüitativas, idênticas às que prevalecem no mercado ou em que a companhia contrataria com terceiros.

$\S 2^{\circ} \mathrm{O}$ negócio contratado com infração do disposto no $\S 1^{\circ}$ é anulável, e o administrador interessado será obrigado a transferir para a companhia as vantagens que dele tiver auferido.”.

${ }^{83}$ Artigo 245 da LSA.
} 
direito inclui-se entre os essenciais, previstos no art, 109 da lei, qual seja o de fiscalizar. Trata-se de prerrogativa que não admite restrição. (...) a presente norma tem por função assegurar meios à companhia (...) de coibir o insider trading por parte do administrador. (...) A publicidade de fato relevante (full disclosure) é o sistema que coloca os acionistas da companhia e os investidores em situação de avaliarem a oportunidade, o preço e as condições dos negócios de aquisição, e a alienação de valores mobiliários emitidos pela companhia." ${ }^{84}$.

O administrador de companhias de capital aberto, ao firmar seu respectivo termo de posse, deverá declarar o número de ações, o bônus de subscrição, as opções de compra de ações e debêntures conversíveis em ações de que seja titular, seja de emissão da companhia na qual exerce o cargo de administrador ou nas sociedades controladas ou do mesmo grupo desta companhia ${ }^{85}$.

Ainda, nos termos do parágrafo primeiro do artigo 157 da LSA, o administrador de uma companhia aberta tem como obrigação revelar à assembléia geral ordinária, sempre que sócios que representem 5\% ou mais capital social solicitarem: (a) o número dos valores mobiliários que tiver adquirido ou alienado, diretamente ou através de outras pessoas, no exercício anterior, seja por meio de emissão realizada pela companhia, de sociedades controladas ou de sociedades do mesmo grupo; (b) as opções de compra de ações que tiver contratado ou exercido no exercício anterior; (c) os benefícios ou vantagens, indiretas ou complementares, que tenha recebido ou esteja recebendo da companhia e de sociedades coligadas, controladas ou do mesmo grupo; (d) as condições dos contratos de trabalho que tenham sido firmados pela companhia com os diretores e empregados de alto nível; e (e) quaisquer atos ou fatos relevantes nas atividades da companhia.

Nesse sentido, também é responsabilidade do administrador, conforme parágrafo sexto do artigo 157 da LSA,

\footnotetext{
${ }^{84}$ CARVAlHOSA, Modesto. Comentários à Lei de Sociedades Anônimas. Vol. $3^{\circ} .4^{\mathrm{a}}$ ed. São Paulo: Saraiva, 2009. p 331 e 333.

${ }^{85}$ Artigo 157 da LSA.
} 
"informar imediatamente, nos termos e na forma determinados pela Comissão de Valores Mobiliários, a esta e às bolsas de valores ou entidades do mercado de balcão organizado nas quais os valores mobiliários de emissão da companhia estejam admitidos à negociação, as modificações em suas posições acionárias na companhia”.

Aqui cabe ressaltar que as informações prestadas pelo administrador serão utilizadas com alguns limites, sempre no interesse da companhia, respondendo os solicitantes pelos prejuízos causados ao administrador pelo uso indevido das informações prestadas.

Também é de responsabilidade dos administradores das companhias abertas comunicar à bolsa de valores e divulgar pela imprensa as deliberações tomadas em assembléia geral ou pelos órgãos de administração da companhia, ou, ainda, os fatos relevantes ocorridos nos negócios da companhia, que possam influenciar a decisão dos investidores do mercado, de modo ponderável, acerca da venda ou compra dos valores mobiliários emitidos pela companhia, conforme parágrafo $4^{\circ}$ do artigo 157 da LSA.

Quanto aos atos ou fatos relevantes ocorridos no âmbito da companhia aberta que tenha relevância para afetar de modo ponderável a decisão em relação à venda ou compra dos valores mobiliários emitidos pela companhia, o parágrafo quinto do artigo 157 da LSA permite que os administradores da companhia recusem-se a informá-los ou a publicá-los, caso estes venha entendam que, ao revelar tais atos ou fatos, estarão colocando em risco algum interesse legítimo da companhia. Cabe à CVM decidir sobre a necessidade da prestação da informação e responsabilizar os administradores se estes agirem além dos limites dessa permissão.

Quanto ao dever de informar, comenta Fábio Ulhôa:

"O aspecto mais importante do direito de informar, contudo, diz respeito às comunicações ao mercado. Assim, o administrador deve informar à CVM, bem como à bolsa de valores ou EMBO em que os valores mobiliários da companhia são negociáveis, qualquer modificação em sua posição acionária; isto é, qualquer compra ou venda de ações emitidas pela companhia (LSA, art. 157, § 6-). Aliás, para garantir a plena informação do mercado, idêntica obrigação é também 
imposta ao controlador (art. 116-A) e aos membros do conselho fiscal (art. 165-A) das companhias abertas." ${ }^{\text {. }}$.

\subsubsection{RESPONSABILIDADE POR DISTRIBUIÇÃO IRREGULAR DE DIVIDENDOS}

Em relação às sociedades anônimas, conforme o parágrafo $1^{\circ}$ do artigo 201 da $\mathrm{LSA}^{87}$, temos que a distribuição de dividendos com inobservância do disposto no referido artigo implicará responsabilidade solidária dos administradores, que serão responsáveis por repor à caixa social a importância distribuída.

Modesto Carvalhosa ${ }^{88}$, no comentário à LSA, entende que em princípio os administradores são solidariamente responsáveis pela distribuição ilegal de dividendos, entendendo ocorrer tal irregularidade quando forem distribuídos na ausência de lucros no exercício, ou de lucros acumulados ou de reserva de lucros, também quando houver prejuízos anteriormente apurados iguais ou superiores ao último resultado positivo ou se distribuírem dividendos às ações preferenciais à conta de reserva de capital havendo lucros suficientes para essa mesma distribuição.

Ainda, os administradores também poderão ser responsabilizados criminalmente por distribuir lucros ou dividendos fictícios:

“Art. 177 - Promover a fundação de sociedade por ações, fazendo, em prospecto ou em comunicação ao público ou à assembléia, afirmação falsa sobre a constituição da sociedade, ou ocultando fraudulentamente fato a ela relativo:

${ }^{86}$ COELHO, Fábio Ulhôa. Curso de Direito Comercial. Vol. II. 9a ed. São Paulo: Saraiva, 2006. p 247.

${ }^{87}$ Artigo 201 da LSA “A companhia somente pode pagar dividendos à conta de lucro líquido do exercício, de lucros acumulados e de reserva de lucros; e à conta de reserva de capital, no caso das ações preferenciais de que trata o $\S 5^{\circ}$ do artigo 17 .

$\S 1^{\circ}$ A distribuição de dividendos com inobservância do disposto neste artigo implica responsabilidade solidária dos administradores e fiscais, que deverão repor à caixa social a importância distribuída, sem prejuízo da ação penal que no caso couber.

$\S 2^{\circ}$ Os acionistas não são obrigados a restituir os dividendos que em boa-fé tenham recebido. Presume-se a má-fé quando os dividendos forem distribuídos sem o levantamento do balanço ou em desacordo com os resultados deste."

${ }^{88}$ CARVAlHOSA, Modesto. Comentários à Lei de Sociedades Anônimas. Vol. $3^{\circ} .4^{\mathrm{a}}$ ed. São Paulo: Saraiva, 2009. p 839. 
Pena - reclusão, de um a quatro anos, e multa, se o fato não constitui crime contra a economia popular.

$\S 1^{\circ}$ - Incorrem na mesma pena, se o fato não constitui crime contra a economia popular:

(...)

VI - o diretor ou o gerente que, na falta de balanço, em desacordo com este, ou mediante balanço falso, distribui lucros ou dividendos fictícios;”

\subsection{OUTRAS HIPÓTESES DE RESPONSABILIZAÇÃO DOS ADMINISTRADORES NAS SOCIEDADES EMPRESÁRIAS}

\subsubsection{RESPONSABILIDADE NO ÂMBITO DO CÓDIGO PENAL}

De acordo com o artigo 177 do Decreto Lei 2.848/40 que instituiu o Código Penal Brasileiro (“CP”), temos como tipo penal a fundação de sociedade por ações fazendo afirmação falsa sobre a constituição da companhia ou ocultando, fraudulentamente, fato relativo à companhia em prospecto ou em comunicação ao público ou à assembléia.

A pena aplicável àqueles que incorrem no referido tipo penal será de reclusão, de um a quatro anos e multa, caso o fato não constitua crime contra a economia popular.

Nesse sentido, incorre na mesma pena o administrador da companhia, que: (a) em prospecto, relatório, parecer, balanço ou comunicação ao público ou à assembléia, fizer afirmação inverídica acerca das condições econômicas da companhia, ou ocultar fraudulentamente, no todo ou em parte, fato a elas relativo; (b) promover, por qualquer artifício, falsa cotação das ações ou de outros títulos da companhia; (c) tomar empréstimo à companhia ou usa, em proveito próprio ou de terceiro, dos bens ou haveres da companhia, sem prévia autorização da assembléia geral; (d) comprar ou vender, por conta da companhia, ações por ela emitidas, salvo quando a lei o permite; (e) aceitar em penhor ou em caução ações da própria companhia como garantia de crédito social; (f) na falta de balanço, em desacordo com este, ou mediante balanço falso, distribuir lucros ou 
dividendos fictícios; e (g) por interposta pessoa, ou conluiado com acionista, conseguir a aprovação de conta ou parecer.

Da mesma maneira, respondem, também, (a) o liquidante, nas hipóteses mencionadas acima (ressalvada a hipótese mencionada no item (g) acima); e (b) o representante de companhia estrangeira, autorizada a funcionar no Brasil, que pratica os atos mencionados nas hipóteses (a) e (b), ou dá falsa informação ao governo.

Ainda, conforme artigo 359-H do CP, responderá criminalmente o administrador que:

"Ordenar, autorizar ou promover a oferta pública ou a colocação no mercado financeiro de títulos da dívida pública sem que tenham sido criados por lei ou sem que estejam registrados em sistema centralizado de liquidação e de custódia:

Pena - reclusão, de 1 (um) a 4 (quatro) anos.

I - com inobservância de limite, condição ou montante estabelecido em lei ou em resolução do Senado Federal;

II - quando o montante da dívida consolidada ultrapassa o limite máximo autorizado por lei.”

\subsubsection{RESPONSABILIDADE POR CONDUTAS LESIVAS AO MEIO AMBIENTE}

A responsabilização dos administradores por danos causados ao meio ambiente tem como base constitucional o artigo 225 da CF, mais especificamente seu parágrafo $3^{\text {o89 }}$.

Nesta hipótese o administrador poderá ser responsabilizado pelos danos ao meio ambiente que der causa.

${ }^{89}$ Artigo 225 da CF "Todos têm direito ao meio ambiente ecologicamente equilibrado, bem de uso comum do povo e essencial à sadia qualidade de vida, impondo-se ao Poder Público e à coletividade o dever de defendê-lo e preservá-lo para as presentes e futuras gerações. (...) $\S 3^{\circ}$ As condutas e atividades consideradas lesivas ao meio ambiente sujeitarão os infratores, pessoas físicas ou jurídicas, a sanções penais e administrativas, independentemente da obrigação de reparar os danos causados.”. 
Nesse sentido, a Lei 9.605/98 (“Lei de Crimes Ambientais”), por meio de seu artigo $2^{\text {o90 }}$, dispõe que o administrador que der causa, concorrer ou deixar de evitar a prática de crimes ambientais, previstos na referida lei, será responsabilizado nos termos das penas cabíveis, na medida de sua culpabilidade.

Frisa-se que, tendo em vista a importância do meio ambiente para a sociedade, esta é uma das hipóteses de responsabilização mais discutidas atualmente e que vem ganhando maior extensão, sendo, inclusive, causa para desconsideração da personalidade jurídica das sociedades empresárias e causa de afastamento de alguns dos mecanismos de proteção ao patrimônio dos administradores (conforme Capítulo 6 abaixo).

\subsubsection{RESPONSABILIDADE NO ÂMBITO TRABALHISTA E PREVIDENCIÁRIO}

Os administradores de empresas que forem responsáveis pela suspensão do trabalho sem prévia autorização do Tribunal competente ou que violarem ou se recusarem a cumprir decisão proferida em dissídio coletivo, incorrerão em perda do cargo de representação profissional em cujo desempenho estiverem, e suspensão, pelo prazo de dois a cinco anos, do direito de serem eleitos para cargos de representação profissional.

Referida hipótese encontra-se positivada através do artigo 722 do Decreto Lei 5452/1943 que instituiu a Consolidação das Leis do Trabalho (“CLT”).

Ainda no âmbito trabalhista, será responsabilizado o administrador que não der cumprimento ao precatório expedido pelo Presidente do

\footnotetext{
90 Artigo $2^{\circ}$ da Lei de Crimes Ambientais “Art. $2^{\circ}$ Quem, de qualquer forma, concorre para a prática dos crimes previstos nesta Lei, incide nas penas a estes cominadas, na medida da sua culpabilidade, bem como o diretor, o administrador, o membro de conselho e de órgão técnico, o auditor, o gerente, o preposto ou mandatário de pessoa jurídica, que, sabendo da conduta criminosa de outrem, deixar de impedir a sua prática, quando podia agir para evitá-la.”.
} 
Tribunal de Justiça local, a requerimento da instituição interessada, tendo em vista o quanto disposto pela Lei ${ }^{\circ}$. 3807/1960, em seu Artigo 85:

\begin{abstract}
“A cobrança judicial de quantias devidas às instituições de previdência, por empresa que tenha legalmente assegurada a impenhorabilidade de seus bens, será executada, depois de transitada em julgado a sentença condenatória, mediante precatório expedido à empresa pelo Presidente do Tribunal de Justiça local, a requerimento da instituição interessada, incorrendo nas penas do crime de desobediência, além da responsabilidade funcional cabível, o respectivo diretor ou administrador, se não der cumprimento ao precatório, no prazo máximo de 30 (trinta) dias."
\end{abstract}

Por fim, nos termos do artigo 337-A do CP, será o administrador pessoalmente responsável pela falta de recolhimento das contribuições e outras importâncias devidas às instituições de previdência.

\title{
5.3.4. RESPONSABILIDADE NO ÂMBITO FALIMENTAR
}

A responsabilização dos administradores das sociedades empresárias falidas pode ocorrer no âmbito civil ou penal, em observância ao disposto nos artigos 82, 168 e seguintes da LRF, podendo ser apurada independentemente da realização do ativo e da prova da sua insuficiência para cobrir o passivo, observado o procedimento ordinário previsto no CPC.

Como vimos, a responsabilidade civil dos administradores fica circunscrita aos atos causadores de prejuízo às sociedades empresárias ocasionados por culpa, dolo ou violação da lei ou do estatuto/contrato social.

Nesse sentido, versa o artigo 82 da LRF que a responsabilidade pessoal dos será apurada no próprio juízo da falência, independentemente da realização do ativo e da prova da sua insuficiência para cobrir o passivo, podendo o juiz, de ofício ou mediante requerimento das partes interessadas, ordenar a indisponibilidade de bens particulares dos réus da referida ação, em quantidade compatível com o dano provocado, até o julgamento da ação de responsabilização. 
Referida medida, contudo, deve ser exercida com cautela pelo juiz da falência, pois o falido não deve/pode ser considerado, em princípio, um fraudador.

No âmbito da responsabilização penal, temos que os administradores das empresas equiparam-se à empresa falida para, entre outros, os efeitos penais, tendo em vista o conteúdo do artigo 179 da LRF, que dispõe que:

\footnotetext{
"na falência, na recuperação judicial e na recuperação extrajudicial de sociedades, os seus sócios, diretores, gerentes, administradores e conselheiros, de fato ou de direito, bem como o administrador judicial, equiparam-se ao devedor ou falido para todos os efeitos penais decorrentes desta Lei, na medida de sua culpabilidade.”
}

Nesse sentido, levando em consideração as disposições legais da LRF, a responsabilidade penal dos administradores no âmbito falimentar pode ser esquematizada da seguinte maneira: (a) crimes decorrentes de atos anteriores à falência ou à recuperação: (i) fraude contra credores ${ }^{91}$, (ii) omissão de lançamento que devia constar das escriturações $^{92}$, (iii) destruição, inutilização ou supressão, total ou parcial, dos documentos contábeis obrigatórios ou dos dados contábeis ou negociais ${ }^{93}$, (iv) simulação da composição do capital social ${ }^{94}$, (v) falsificação material da escrituração obrigatória, (vi) contabilidade paralela ${ }^{95}$, e (vii) violação de sigilo empresarial ${ }^{96}$; ou (b) crimes decorrentes de atos praticados durante a falência ou a recuperação: (i) indução a erro $^{97}$, (ii) divulgação de informações falsas ${ }^{98}$, (iii) favorecimento de credores $^{99}$, (iv) desvio, ocultação ou apropriação de bens ${ }^{100}$, (v) aquisição, recepção ou uso ilegal de

\footnotetext{
91 Artigo 168 da LRF.

92 Artigo 168, § $1^{\circ}$, II, da LRF.

93 Artigo 168, § $1^{\circ}$, V, da LRF.

94 Artigo 168, § $1^{\circ}$, IV, da LRF.

95 Artigo 168, § 2º da LRF.

96 Artigo 169 da LRF.

97 Artigo 171 da LRF.

98 Artigo 170 da LRF.

99 Artigo 172 da LRF.

${ }^{100}$ Artigo 173 da LRF.
} 
bens pertencentes à massa falida ${ }^{101}$, (vi) habilitação ilegal de crédito na falência ou na recuperação judicial ou extrajudicial ${ }^{102}$, (vii) exercício ilegal da atividade para qual foi inabilitado ${ }^{103}$, (viii) violação de impedimento ${ }^{104}$, e (ix) omissão de documentos contábeis obrigatórios ${ }^{105}$ ou sua escrituração atrasada, lacunosa, defeituosa ou confusa.

Nos termos do artigo 181 da LRF, temos que a condenação por crime falimentar poderá vir a implicar (a) na inabilitação para o exercício de atividade empresarial; (b) no impedimento para o exercício de cargo de administração; e (c) e na impossibilidade de gerir empresa por mandato ou por gestão de negócio. Observados quaisquer desses efeitos em razão de sentença condenatória transitada em julgado, temos que os mesmos perdurarão por até cinco anos após a extinção da punibilidade, podendo, contudo, cessar antes pela reabilitação penal.

Ressalta-se, por fim, que, com base no artigo 99, inciso VII, da LRF, pode o juiz determinar a prisão preventiva dos administradores das sociedades empresárias quando requerida com fundamento em prova de prática de crime falimentar.

\subsubsection{RESPONSABILIDADE NO ÂMBITO FISCAL}

Conforme o inciso III do artigo 135 da Lei $\mathrm{n}^{\circ}$. 5.172/1966 que instituiu o Código Tributário Nacional ("CTN”), temos que os administradores são pessoalmente responsáveis pelos créditos tributários resultantes de atos praticados com excesso de poderes ou infração de lei, contrato social ou estatutos.

Assim como dispõe a legislação comercial, compreende-se que a regra geral no direito tributário é de que o administrador de uma sociedade

\footnotetext{
${ }^{101}$ Artigo 174 da LRF.

102 Artigo 175 da LRF.

${ }^{103}$ Artigo 176 da LRF.

${ }^{104}$ Artigo 177 da LRF.

${ }^{105}$ Artigo 178 da LRF.
} 
empresária não responde pessoalmente pelos tributos devidos pela sociedade, salvo se tais obrigações tributárias forem decorrentes de atos dolosamente praticados com excesso de poder ou infração de lei vigente ou ao estatuto social. Neste sentido, vale transcrever a lição de Hugo de Brito Machado:

\begin{abstract}
"De todos esses dispositivos legais se conclui que a regra é a de que os diretores, gerentes ou representantes de pessoas jurídicas de direito privado não respondem pessoalmente pelos tributos devidos por tais pessoas jurídicas. E a exceção é a de que existirá tal responsabilidade em se tratando de créditos decorrentes de obrigações tributárias resultantes de atos praticados com excesso de poderes ou infração de lei, contrato ou estatuto social”"106 .
\end{abstract}

Porém, cabe ressaltar que não existe consenso doutrinário ou jurisprudencial sobre o sentido que se deve dar à expressão "infração da lei”, utilizado pelo referido dispositivo legal do CTN.

Existem entendimentos de que o simples não recolhimento do tributo seria suficiente para acarretar a responsabilidade pessoal dos administradores ${ }^{107}$.

Por outro lado, encontramos autores e interpretação jurisprudencial de que o não-recolhimento de tributos não configura infração à lei hábil a permitir a responsabilização dos administradores, uma vez que não cabe falar em responsabilidade objetiva no âmbito referido dispositivo ${ }^{108}$.

Situação diversa ocorre quando o administrador de uma pratica atos diretamente contrários à lei ou ao disposto no estatuto social (e.g. ocultação de receitas ou adulteração de balanços). Nestes casos, não há que se negar a responsabilidade pessoal dos administradores, sendo os administradores responsáveis por suportar os prejuízos decorrentes de seus atos, na medida da sua culpabilidade.

106 MACHADO, Hugo de Brito. Curso de Direito Tributário. 23ª ed. São Paulo: Malheiros, 2003, p 126.

107 MARTINS, Sérgio Pinto. Manual de Direito Tributário. 1a ed. São Paulo: Atlas, 2002. p 169 e 170; e STJ, REsp n. 33731/MG, Rel. Ministro Milton Luiz Pereira, Brasília, 6 mar. 1995.

108 MACHADO, Hugo de Brito. Curso de Direito Tributário. 23a ed. São Paulo: Malheiros, 2003, p. 126; e STF, RExt n. 85.241/SP, Rel. Ministro Leitão de Abreu, Brasília, 22 nov. 1977. 
Finalmente, vale ressaltar que cabe à Fazenda Nacional a prova da prática de atos contrários à lei ou ao estatuto/contrato social. Sem provas por parte da Fazenda Nacional não será possível responsabilizar tributariamente os administradores. 


\section{PRÁTICAS PARA PRESERVAÇÃO DO PATRIMÔNIO DOS ADMINISTRADORES}

Existem, atualmente, duas práticas adotadas em grande escala pelas sociedades empresárias visando à preservação do patrimônio dos seus administradores, quais sejam:

\subsection{ACORDO DE INDENIDADE (HOLD HARMLESS LETTER)}

O acordo de indenidade é uma imitação do instituto da Hold Harmless Letter do Direito Norte Americano. Referida prática consiste na celebração de um acordo cujo objeto é a manutenção da indenidade do administrador frente à sua responsabilização por exercer tal cargo. A proteção oferecida por este acordo inclui eventuais despesas com honorários profissionais ou ônus necessários à discussão de demandas (e.g. garantias, depósito judiciais, etc).

Contudo, respeitando o espírito da lei, o referido acordo não é eficaz contra os atos praticados pelos administradores com culpa ou dolo ou em violação à lei e/ou ao contrato/estatuto social das sociedades.

Nesse acordo temos como parte a sociedade e o administrador, onde a sociedade figura como uma espécie de garantidora dos prejuízos patrimoniais que o administrador venha a sofrer em razão das funções que exerce em nome sociedade de forma legítima.

\subsection{SEGURO PARA RESPONSABILIDADE CIVIL DE ADMINISTRADORES (DIRECTORS AND OFFICERS INSURANCE)}

Igualmente, o Seguro para Responsabilidade Civil de Administradores foi um instituto importado do Direito Norte Americano (conhecido naquela jurisdição como Directors and Officers Insurance - 
“D\&O”) Trata-se de uma espécie de seguro que visa atuar com o mesmo objeto que o acordo de indenidade.

Normalmente, a decisão entre a contratação do D\&O ou da hold harmless letter tem como base o potencial de risco de responsabilização dos administradores em razão das atividades exercidas em nome das sociedades. O D\&O é utilizado nos casos em que os riscos e valores envolvidos são mais expressivos, uma vez que é a seguradora que ressarcirá os prejuízos e não a sociedade em si.

As pessoas protegidas por tal espécie de seguro são aquelas que exercem cargos de administração nas sociedades empresárias (i.e. conselheiros e diretores), tanto os estatutários quanto os empregados, e quem contrata o D\&O é a sociedade (sempre em benefício dos administradores).

Vale ressaltar, também, que o D\&O pode vir a apresentar cobertura em escala mundial e até mesmo para garantir fatos pretéritos a sua contratação ${ }^{109}$.

Referido seguro cobre os prejuízos reclamados por terceiros, que são compostos pelas despesas (e.g. honorários advocatícios e custas judiciais) e indenizações (e.g. condenações e acordos em razão de processos e/ou pleitos de terceiros que venham a afetar o patrimônio dos administradores) imputadas aos administradores exclusivamente em decorrência do legítimo exercício de seus cargos.

Contudo, no âmbito de proteção do D\&O é controversa sua eficácia frente a multas e indenizações por danos ambientais. Não obstante referida controvérsia, observa-se que as seguradoras já vêm apresentando essas proteções nos seguros oferecidos às sociedades empresárias.

Conforme dados da Superintendência de Seguros Privados (“SUSEP”), o Brasil, dentro da América Latina, é o país com maior número de D\&Os celebrados.

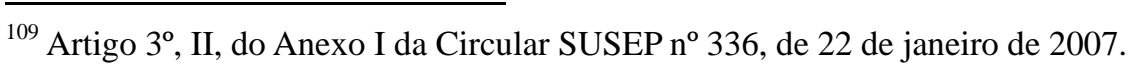


Vale ressaltar, por fim, que os maiores reclamantes do uso do instituto do D\&O são a CVM, a Fazenda Pública e os órgãos de fiscalização ambiental em geral.

Nesse sentido, de acordo com a Instrução CVM 480, publicada em dezembro de 2009, as companhias abertas que celebrarem o D\&O devem informar à CVM e, conseqüentemente, ao mercado sobre

“as disposições de quaisquer acordos, inclusive apólices de seguro, que prevejam o pagamento ou o reembolso de despesas suportadas pelos administradores, decorrentes da reparação de danos causados a terceiros ou ao emissor, de penalidades impostas por agentes estatais, ou de acordos com o objetivo de encerrar processos administrativos ou judiciais, em virtude do exercício de suas funções.” ${ }^{110}$.

${ }^{110}$ Item 12.11 da Instrução CVM 480 de dezembro de 2009. 


\section{CONCLUSÃO}

Tendo em vista todo o exposto, observa-se que existem diversas hipóteses de responsabilização do administrador das sociedades empresárias, seja de natureza pessoal ou solidaria, com efeitos administrativos, cíveis ou criminais.

No entanto, em regra, o administrador apenas será responsabilizado pelos atos que praticar com culpa ou dolo em razão do exercício do seu cargo (e.g. omissão, imperícia ou imprudência no exercício das atividades a ele inerentes) ou pelos atos praticados em violação à legislação, ao contrato/estatuto social ou aos fins sociais e a função social da sociedade/companhia.

Cabe ressaltar, ainda, que de maneira alguma tais hipóteses de responsabilização devem ser consideradas como abusivas ou desnecessárias, uma vez que (a) as sociedades empresárias podem facilmente servir de objeto para fraudar a lei e (b) os administradores de uma sociedade empresária encontram-se em determinada posição que os permite tanto impedir ou dificultar o uso da sociedade empresária para fins fraudulentos como se beneficiar e atuar no âmbito destas fraudes.

Porém, mesmo tais institutos sendo necessários, sua variedade e inúmeras hipóteses de aplicação geram, também, insegurança na pessoa física em assumir cargos de administração e, muitas vezes, tomar decisões mais agressivas que garantiriam maior sucesso à sociedade/companhia.

Por isso, são igualmente necessários os institutos do $D \& O$ e da hold harmless letter, os quais visam garantir determinada segurança para aqueles que exercem cargos de administração nas sociedades empresárias.

Por fim, contudo, ressalva-se que tais alternativas de proteção contra as hipóteses de responsabilização dos administradores jamais deverão servir de instrumentos para incentivar a prática de atos que visem burlar a lei, o estatuto/contrato social e/ou os fins sociais. 


\section{REFERÊNCIAS BIBLIOGRÁFICAS}

BORBA, José Edwaldo Tavares. Direito Societário. 8a ed. Rio de Janeiro: Renovar, 2003. p 18.

CARVALHOSA, Modesto. Comentários à Lei de Sociedades Anônimas. Vol. $3^{\circ} .4^{\text {a }}$ ed. São Paulo: Saraiva, 2009. p 311, 331, 333 e 839.

CAMPINHO, Sérgio. O Direito de Empresa à Luz do Novo Código Civil. $8^{\mathrm{a}}$ ed. Rio de Janeiro: Renovar, 2008. p 281 e 282.

COELHO, Fábio Ulhôa. Curso de Direito Comercial. Vol. II. 9a ed. São Paulo: Saraiva, 2006. p. 13,14, 28, 43, 45, 46, 63, 244, 245, 247, 250 e 364.

Manual de Direito Comercial. 15a ed. São Paulo: Saraiva, 2004. p 153 e 154.

JUNIOR, Darcy Arruda Miranda. Breves Comentários à Lei de Sociedades por Ações. $1^{a}$ ed. São Paulo: Saraiva, 1977, p. 224.

NETTO, Nelson Rodrigues. Responsabilidade Civil dos Administradores das Sociedades Anônimas. Revista Forense. Vol. 358. p 141 e 142.

MACHADO, Hugo de Brito. Curso de Direito Tributário. 23 ${ }^{\mathrm{a}}$ ed. São Paulo: Malheiros, 2003, p 126.

MARTINS, Sérgio Pinto. Manual de Direito Tributário. $1^{\text {a }}$ ed. São Paulo: Atlas, 2002. p 169 e 170.

JORGE, Tarsis Nametala Sarlo Jorge. Manual das Sociedades Limitadas.1 ${ }^{\mathrm{a}}$ ed. Rio de Janeiro: Lumen Júris, 2007. p 292 e 295. 
STF, RExt n. 85.241/SP, Rel. Ministro Leitão de Abreu, Brasília, 22 nov. 1977.

STJ, REsp n. 33731/MG, Rel. Ministro Milton Luiz Pereira, Brasília, 6 mar. 1995.

STJ, REsp n. 279273/SP, Rel. Ministro Ari Pargendler, 4 dez. 2003.

TJRJ, Agrav. Inst. n. 2010.002.0161-6, Des. Rogério de Oliveira Souza, 9a Câmara Cível, Rio de Janeiro, 13 abr. 2010. 